\title{
Geology of the Southern Himalaya In Hazara, Pakistan, and
}

Adjacent Areas

GEOLOGICAL SURVEY PROFESIONAL PAPER 716-C

Prepared in cooperation with the Geological Survey of Pakistan, under the auspices of the Government of Pakistan and the Agency for International Development, U.S. Department of State

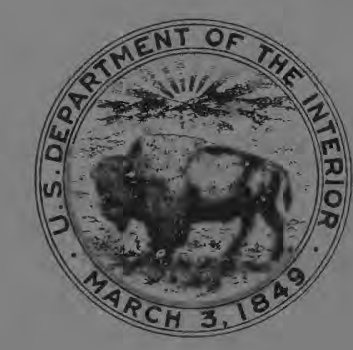




\section{Geology of the Southern Himalaya In Hazara, Pakistan, and}

\section{Adjacent Areas}

By JAMES A. CALKINS and TERRY W. OFFIELD, U.S. GEologicAl Survey, and

S. K. M. ABDULlAH and $S$. TAYYAB ALI, Geological Survey of Pakistan

GEOLOGICAL INVESTIGATIONS IN PAKISTAN

GEOLOGICAL SURVEY PROFESSIONAL PAPER 716-C

Prepared in cooperation with the Geological Survey of Pakistan, under the auspices of the Government of Pakistan and the Agency for International Development, U.S. Department of State

The rocks of the Hazara-Kashmir syntaxis and adjacent western arc range in age from Precambrian to Tertiary

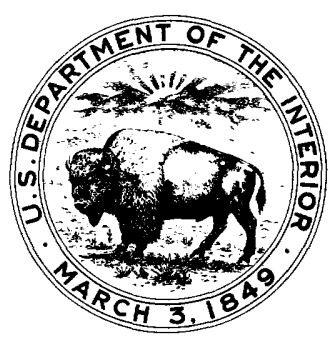
and are characterized by overturned folds and strike-slip reverse faults 


\section{UNITED STATES DEPARTMENT OF THE INTERIOR \\ ROGERS C. B. MORTON, Secretary}

\section{GEOLOGICAL SURVEY}

V. E. McKelvey, Director

Library of Congress catalog-card No. 73-600261 


\section{FOREWORD}

In 1956, the Geological Survey of Pakistan and the U.S. Geological Survey began a cooperative program to intensify the mapping and appraisal of the geological resources of Pakistan. The program was initiated under an agreement dated October 1955 between the Government of Pakistan and the International Cooperation Administration, predecessor of the Agency for International Development, U.S. Department of State. It included joint geological reconnaissance of unmapped areas, detailed mapping and appraisal of mineral districts, and development of facilities and staff to increase the capacity of the Geological Survey of Pakistan.

This volume entitled "Geological Investigations in Pakistan" is intended to present some of the more significant results of the cooperative program in Pakistan, which extended from 1956 to 1970. It consists of papers that have been prepared by U.S. Geological Survey geologists and by their counterparts in the Geological Survey of Pakistan, summarizing the investigations believed to be most important for those interested in the geology and resources of Pakistan. More detailed information from these investigations, as well as reports from other studies made during the program, are available from the Geological Survey of Pakistan in Quetta. Much of the regional geological information obtained during this program, and from surveys made earlier, was summarized in a new Geological Map of Pakistan prepared cooperatively and published by the Geological Survey of Pakistan in 1964.

The cooperative program in Pakistan, which directly involved the services of about 110 professional personnel from Pakistan and 43 from the United States, operated successively under the direction of four Directors-General of the Geological Survey of Pakistan and three Chiefs of Party appointed by the U.S. Geological Survey. Program directors for Pakistan were E. R. Gee (1956 59), N. M. Khan (1959-64), A. F. M. M. Haque (1964-69), and A. M. Khan (1969-70). United States participation was supervised by J. A. Reinemund (1956-63), M. G. White (1963-66), and D. L. Rossman (1967-70), each of whom also served as senior geologic consultant to the Director-General.

Geologic specialists provided by the U.S. Geological Survey were supplemented by four mining engineers from the U.S. Bureau of Mines, who provided collateral assistance to the Pakistan Department of Mineral Development, and by a drilling specialist and an administrative specialist from the Agency for International Development. The Geological Survey of Pakistan, through the Ministry of Industries and Natural Resources, provided counterpart personnel facilities, and services for the program, and arranged cooperative support from the Pakistan Department of Mineral Development, as well as from the Pakistan Industrial Development Corporation, Pakistan Council of Scientific and Industrial Research, and other agencies concerned with resource development. 
This program would not have been possible without the excellent support of all agencies involved, both in Pakistan and the United States. The geological information and institutional growth obtained through this program should contribute significantly toward orderly economic and scientific development in one of Asia's largest and newest nations.

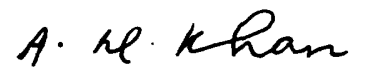

Abdul Mannan Khan, Director-General Geological Survey of Pakistan

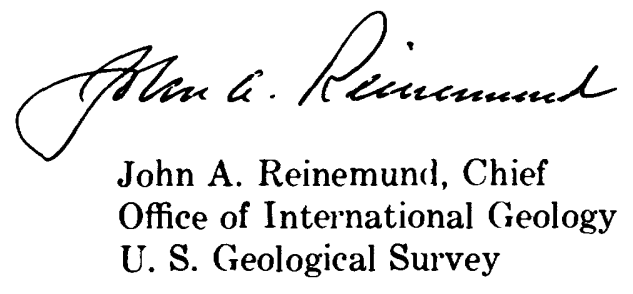




\section{CONTENTS}

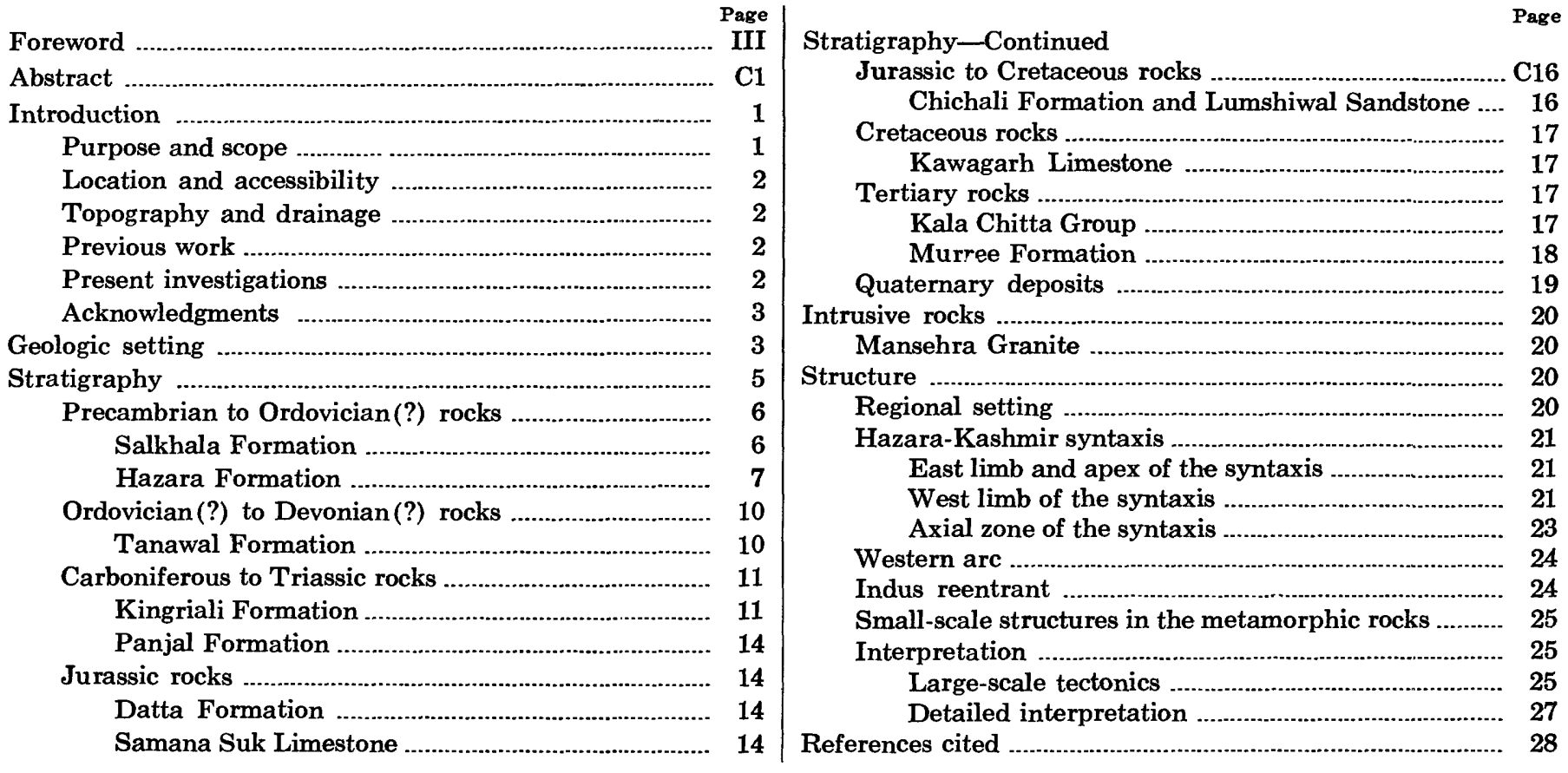

\section{ILLUSTRATIONS}

[Plates are in pocket]

Plate 1. Map of northern Pakistan showing the location of the mapped area and the structural trend lines of the region.

2. Geologic map of the southern Himalaya in Hazara, Pakistan, and adjacent areas.

3. Reconnaissance geologic map and sections of the Tarbela area, Pakistan.

4. Geologic map and sections of the Garhi Habibullah area, Hazara district, Pakistan.

5. Geologic map of the Kakul-Galdanian area, Hazara district, Pakistan.

6. Geologic map and section of the Tarbela damsite area, Pakistan.

1. Generalized structure map and section of the southern Hazara district, Pakistan, and part of western Kart $\mathrm{K}$
2. Correlation of sections in the three structural blocks of the southern Hazara area, Pakistan, and part of western Kashmir.

3. Stratigraphic correlation chart for Hazara and other areas of northern Pakistan 


\title{
GEOLOGY OF THE SOUTHERN HIMALAYA IN HAZARA, PAKISTAN, AND ADJACENT AREAS
}

\author{
By James A. Calkins and Terry W. Offield, U.S. Geological Survey, and \\ S. K. M. Abdullah and S. Tayyab Ali, Geological Survey of Pakistan
}

\begin{abstract}
Geologic mapping and mineral investigations were conducted from 1961 to 1965 by the Geological Survey of Pakistan and the U.S. Geological Survey in the Hazara district, Pakistan, and part of western Kashmir, as part of a cooperative mineral exploration and development program. The area covers 2,000 square miles in the southern foothills of the Himalaya between the Jhelum River on the east and the Indus River on the west. Rugged mountains and deep canyons characterize most of the area. Altitudes range from 1,100 feet on the Indus River near Tarbela to more than 16,000 feet on the Kashmir divide; the Indus, Siran, Kunhar, Kishanganga, and Jhelum Rivers all flow in deep gorges through the area.

The geologic formations range in age from Precambrian to Quaternary and include sedimentary, igneous, and metamorphic rocks and unconsolidated material. The oldest rocks belong to the Salkhala Formation of Precambrian age. Above it are the Hazara Formation (Precambrian(?) and possibly lower Paleozoic), Tanawal Formation (Upper Ordovician(?) to Devonian(?)), Panjal and Kingriali Formations and "Agglomeratic Slate" (Carboniferous to Triassic), Datta Formation (Lower Jurassic), Samana Suk Limestone (Jurassic), Chichali Formation (Upper Jurassic), Lumshiwal Sandstone (Upper Jurassic to Lower Cretaceous), Kawagarh Limestone (Upper Cretaceous), Kala Chitta Group (Paleocene to Eocene), and the Murree Formation (Oligocene(?) to Miocene).

The Mansehra Granite was intruded in Late Cretaceous to early Tertiary time, apparently in the form of one or more sheetlike bodies. Contact-metamorphic effects around the granite generally are not pronounced; however, wollastonite occurs at one locality. Regional metamorphism and accompanying penetrative deformation increase in intensity northward. The regional metamorphism was synchronous with or postdates the granite, because the granite itself is involved in the deformation.

The structural pattern in the mapped area consists of two northward-projecting loops or reentrants-the larger HazaraKashmir syntaxis and the smaller Indus reentrant-connected by a broad arcuate belt, called the western arc. The HazaraKashmir syntaxis, which is the pivot point of the great regional arc of the northwest Himalaya, is oriented slightly west of north and contains younger rocks in its core or axial zone; successively older rocks wrap around the periphery. A system of boundary faults also wraps around the syntaxis and helps to define it. The southern part of the western limb of the syntaxis is divided into three structural blocks separated by
\end{abstract}

major faults which show combined strike-slip and vertical displacement.

The structural development of the Hazara-Kashmir syntaxis is believed to be related to the great regional arc of the Himalaya $\mathbf{1 5 0}$ miles to the north. Southward tectonic transport moving perpendicular to this great arc would converge on the axial zone of the Hazara-Kashmir syntaxis, which is at the pivot point of the arc. The present syntaxial structure would be the natural result of such movement. Late-stage westward countermovement of the rocks in the axial zone resulted in the present westward overturning of the folds along the southern segment of the western limb of the syntaxis.

The Indus reentrant, as with the Hazara-Kashmir syntaxis, also is interpreted to be the result of smaller scale tectonic convergence towards its present axial zone. Between the HazaraKashmir syntaxis and the Indus reentrant, the rocks moved south to form the southward bulge of the western arc.

In terms of large-scale tectonics the Himalayan mountain system has southward asymmetry, which has been interpreted in two ways: (1) radial spreading out southward of middle Asia and (2) continental drift of India against Asia. The latter view has gained credibility recently as a result of new data and ideas on global tectonics.

The earliest known indications of the Himalayan orogeny are found at Hindubagh, near Quetta, where ultramafic rocks were emplaced after Cretaceous but before Eocene time. The widespread episode of folding and mountain building began in Miocene time in the mapped area.

\section{INTRODUCTION}

\section{PURPOSE AND SCOPE}

Geologic and mineral investigations, covering an area of about 2,000 square miles, were conducted jointly by the Geological Survey of Pakistan and the U.S. Geological Survey from 1961 to 1965 in the Hazara district, Pakistan, and in part of Kashmir (pls. 1,2). A small amount of additional work was done during part of 1968. These investigations were part of a mineral exploration and development program sponsored by the Government of Pakistan and the Agency for International Development, U.S. Department of State. The work included the geologic mapping of a block of eight 15-minute quadrangles and detailed mapping of several 
smaller areas. This paper synthesizes the geologic and structural information for the region.

\section{LOCATION AND ACCESSIBILITY}

The area investigated is mostly in the southern part of the Hazara district and includes a small part of Kashmir (pls. 1, 2). Abbottabad, the main city in the area, is 75 miles north of Rawalpindi. Despite the extremely mountainous terrain, the southern Hazara district contains a good network of roads which provides access to most of the area. Large and rugged tracts between the roads, however, are accessible only by footpath, and extended geologic work in these areas required the packing in of tents and supplies. Paved roads include the Hazara Trunk road, the MurreeMuzaffarabad road, and the Haripur-Tarbela road. Dirt roads extend from Abbottabad and Mansehra to several villages to the north, west, and east. Other secondary roads follow most of the main rivers. In the intervening tracts, innumerable footpaths connect the villages and cross all mountain passes.

\section{TOPOGRAPHY AND DRAINAGE}

Rugged mountains and deep canyons characterize most of the area. Altitudes range from 1,100 feet on the Indus River near Tarbela to more than 16,000 feet along the Kashmir divide. Many slopes exceed $35^{\circ}$. Local relief is extreme-from an altitude of 4,952 feet at Mahandri on the Kunhar River, the valley sides rise to 16,505 feet on the Kashmir divide in a distance of only 5 miles. From Kohala on the Jhelum River to Miraniani Peak, the relief is 7,851 feet in 5 miles. The alluvial plains around Mansehra and Haripur are the only flatlands of any extent in the area.

The main rivers, the Indus, Siran, Kunhar, Kishanganga, and Jhelum, all flow in deep gorges through the area. The Kishanganga and the Kunhar join the Jhelum south of Muzaffarabad, and the arcuate course of the Kishanganga reflects the curving trend of the syntaxial bend in the eastern part of the area.

\section{PREVIOUS WORK}

The earliest published work describing the geology of the Hazara area is that of Waagen and Wynne (1872), who studied the stratigraphy of a small area just outside Abbottabad. Another early paper is by Middlemiss (1896); it contains an account of the geology of the Hazara area and includes a geologic map of an area extending from the Black Mountains on the west bank of the Indus eastward to the Kunhar River. These early workers established the broad structuralstratigraphic relationships in the area and named several of the rock units. Wadia (1931) applied the name "syntaxis" to the sharply curving mountain structure in the eastern half of the area.

From 1948 to 1951, A. H. Khan, A. M. Khan, and M. A. Bakr of the Geological Survey of Pakistan mapped the rock types in parts of several quadrangles in the Hazara district, but this work is unpublished. More recently, geologic reports relating to this area have been published by the Punjab University (Shams, 1961; Marks and Ali, 1961; Ali, 1962).

\section{PRESENT INVESTIGATIONS}

The field investigations for this report were made by several geologists, who worked mainly in teams of two or more. The quadrangles and special areas covered by the several teams are shown on the index map of plate 2 .

An initial reconnaissance survey of the southern Hazara area was made in November and December 1961, by S. T. Ali, Calkins, and Offield (mineral and geologic reconnaissance) and by $\mathrm{K}$. W. Stauffer and M. S. Zafar (heavy-mineral sampling).

Geologic quadrangle mapping of the southern Hazara district began in December 1961. The Mansehra quadrangle was mapped between December 1961 and April 1962 by Offield, Abdullah, and Zafar. Fieldwork in the Garhi Habibullah quadrangle and part of the Nathia Gali quadrangle was done by Calkins during the spring and fall months of 1962, 1963, and 1964, with assistance from Zafar in March and April 1962; M. I. Durrazai in June, October, and November 1962; and A. S. A. Matin in June 1963. S. T. Ali, working mainly alone, mapped the Abbottabad quadrangle during parts of 1963 and 1964. Offield and Abdullah completed work in the Balakot and Mahandri quadrangles during the spring and summer months of 1962 and 1963 and in the Darband quadrangle during the fall of 1962. Offield, Calkins, and Afaq Ali completed work in the Tarbela quadrangle during April and May 1964, with assistance from S. I. Ahmad and A. H. Sabri. Fieldwork in the Battal quadrangle was done in the summer and fall months of 1964 by Matin, Afaq Ali, Ahmad, and Sabri, with assistance from Calkins.

The soapstone deposits at Sherwan were mapped by Calkins and Offield in May 1964; the barite deposits at Kohala by F. L. Klinger in September 1963 and by Calkins in March 1964. The iron deposits in Galdanian and Chure Gali were studied by Calkins and Matin in June 1963 and by Calkins in October 1963. A geologic survey of the Tarbela damsite area on the Indus was made by Calkins and M. Ahmad during January and March 1968.

Most of the 15-minute quadrangles were mapped in reconnaissance fashion in 40-50 man-days each, by means of many foot traverses. Aerial photographs were not of much assistance because of the extreme relief, 
widespread forest cover, nature of the bedrock, and the low quality of the photographs. The Garhi Habibullah quadrangle, which took 110 man-days, was mapped mainly in detail, as were the areas of economic interest at Sherwan and Galdanian and the area of the Tarbela damsite, which is of critical interest from the standpoint of engineering geology.

Wherever possible, the field parties operated out of Government Rest Houses in the larger towns and in the Forest Reserves. In the more remote areas they lived in tents or in mountain villages.

The base maps used for the geologic quadrangle mapping were Survey of Pakistan 15-minute topographic sheets enlarged to a scale of $1: 31,680$. In the Sherwan and Galdanian areas the base maps were special stereocompilations at a scale of $1: 12,000$ made by the Photogrammetric Group, Geological Survey of Pakistan.

The geologic quadrangle maps and special maps, as well as information obtained from previously published and unpublished work, are combined and somewhat generalized into a single geologic map of the area (pl. 2 ). The base maps used for this regional compilation were Survey of Pakistan $1^{\circ}$ topographic sheets, enlarged to a scale of $1: 125,000$.

To avoid a loss of information resulting from the reduction in scale, certain areas where a considerable amount of detailed work was done have been retained in their original scales. These are the Tarbela 15minute quadrangle (pl. 3), the Garhi Habibullah 15minute quadrangle (pl. 4), the special map of the Kakul-Galdanian area (pl. 5), and the map of the Tarbela damsite area (pl. 6).

\section{ACKNOWLEDGMENTS}

The full support of the Minister of Industries, Commerce, and Mineral Resources; the Minister of Kashmir Affairs; the Deputy Commissioner of the Hazara District; the geologists of the Water and Power Development Authority at the Tarbela damsite, and other officials of the Government of Pakistan, as well as the Government of Azad Kashmir, is gratefully acknowledged.

The authors appreciate the unpublished geologic information on the Hazara area freely given them by A. H. Khan, A. M. Khan, and M. A. Bakr, Geological Survey of Pakistan. Members of the Department of Geology, Panjab University, who were working in the Hazara area, also generously provided much help and information.

The authors also acknowledge the cooperation and guidance provided by the mine owners, as well as the friendliness and hospitality offered by the local village people throughout the area.

\section{GEOLOGIC SETTING}

The geologic formations of the Hazara district range in age from Precambrian to Quaternary and include sedimentary, igneous, and metamorphic rocks and unconsolidated material. In collaboration with $\mathrm{A}$. $\mathrm{N}$. Fatmi of the Geological Survey of Pakistan, C. E. Meissner of the U.S. Geological Survey, and others, many of the stratigraphic units of Hazara have been correlated with units of the Kala Chitta Hills, 40 miles southwest of Abbottabad and westward to the Kohat area (pl. 1). Certain formations also are correlative with formations at Simla, India, 300 miles to the southeast, and in Kashmir. ${ }^{1}$

The rock units of Precambrian and possibly early Paleozoic age (Salkhala and Hazara Formations) and early and middle Paleozoic age (Tanawal Formation) are mainly clastic, although the Salkhala Formation contains considerable nonclastic carbonate material. A long period of mainly carbonate deposition, extending from the Carboniferous to the Eocene, is recorded in a nearly complete sequence of rock units totaling about 5,500 feet in thickness. Clastic deposits become dominant in the middle and late Tertiary, reflecting the beginning of the Himalayan orogeny, which ultimately deformed all rocks in the region.

The dominant structural feature in the area covered by this report is the bend of about $180^{\circ}$ in the geologic structures and mountain ranges in the eastern half of the area (fig. 1). Wadia (1931), who first studied this feature, called it the "Syntaxis of the North West Himalaya" and the name "Hazara-Kashmir syntaxis" is used in this report. The rock units and major faults follow around this loop and then curve westward in a broad arc toward the Indus River. The development of the syntaxis extended into post-Miocene time, because the Murree Formation (Oligocene(?) to Miocene) is involved. Evidence exists for two main phases of deformation, both of which are part of the Tertiary Himalayan orogeny.

Pre-Tertiary igneous activity is recorded only in the volcanic greenstone and "Agglomeratic Slates" of the Panjal Formation of Carboniferous to Permian age. The main episode of igneous activity took place in Late Cretaceous and early Tertiary time and resulted in the synorogenic intrusions of the Mansehra Granite. These granite rocks are thought to represent the southern fringes of the extensive granite intrusions in the axial zone of the Himalaya. Postorogenic intrusive rocks include mafic dikes and quartz veins, the latter thought to be associated with a phase of weak hydrothermal activity, which produced veins of soapstone and barite.

1 The status of stratigraphic nomenclature of Pakistan and that used in this report is discussed under "Stratigraphy." 


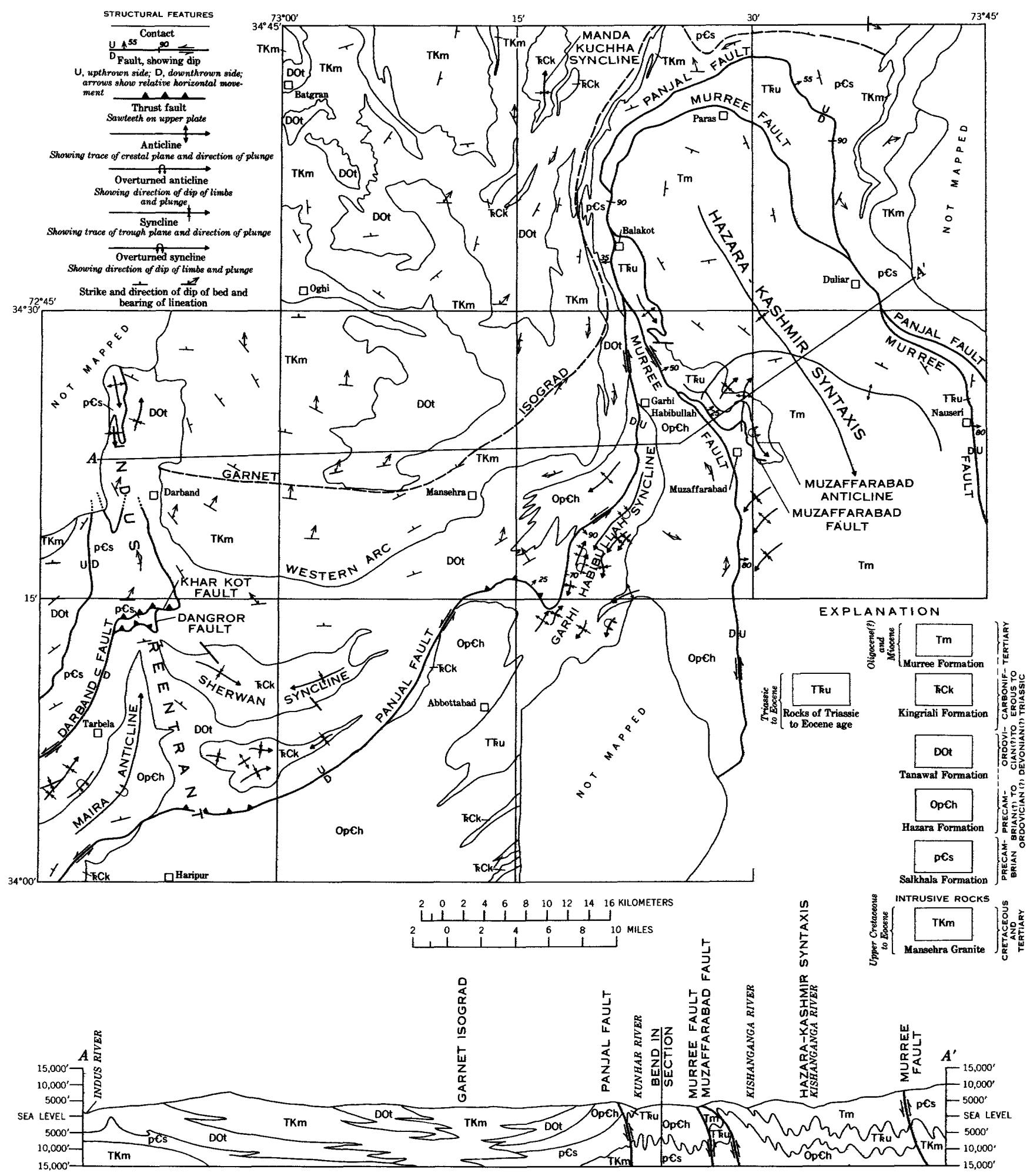

FIGURE 1.-Southern Hazara district, Pakistan, and part of western Kashmir.

Regional metamorphism has affected the Carbonif- Carboniferous) and older rocks, the absence of metaerous and older rocks. Inasmuch as metamorphic grade morphism of these younger rocks is attributed to their does not change abruptly between younger (post- higher position in the crust during metamorphism. In 
general, the grade of regional metamorphism increases northward and also follows around the syntaxial bend. Argillite, phyllite, slate, and quartzose schist, together with essentially unaltered shale, quartzose siltstone, and quartzite, prevail in the southern part of the mapped area. Northward, in the Darband, Oghi, and Battal areas, higher grade metamorphic rocks are universal, including garnet-, kyanite- , staurolite- , and sillimanite-bearing schists, as well as tremolite-bearing marble. The pelitic and quartzose schists of the highgrade metamorphic terrane are considered to be equivalent to the Tanawal Formation and the marble to the Kingriali Formation, although these assignments are not certain. A rough approximation of the garnet isograd, as shown in figure 1 , indicates that the regional metamorphic gradient is not directly controlled by the Mansehra granite, at least along the southern margins of the granite in the western arc area. Other metamorphic isograds are shown on plate 2 . It seems likely that this regional metamorphism is not directly related to the heat from the southern part of the granite, but to a more deeply seated source.

Evidently only one period of metamorphism-that connected with the Himalayan orogeny-has occurred in this area. The essentially unaltered shale, siltstone, and limestone of the Hazara Formation in the southern part of the area tend to preclude a period of metamorphism in the Precambrian and Paleozoic. In addition, the structural continuity between metamorphosed and unmetamorphosed rocks, as well as the involvement of the Mansehra Granite in the deformation, points to the close relationship between the Tertiary Himalayan orogeny and the metamorphism.

Contact-metamorphic effects in the rocks adjacent to the Mansehra Granite are not particularly striking. In some places a narrow zone of cordierite and andalusite schist has formed, but in other places virtually no contact effects were noted. In the Balakot area, carbonate rocks adjacent to granite have been somewhat altered to calc-silicate rocks. Near Chitta Batta, 4 miles northeast of Mansehra, Shams (1963) noted garnet, epidote, and wollastonite in calcareous nodules within the Tanawal Formation, which shows that, in some places at least, contact-metamorphic effects are fairly strong. The interrelationships between regional metamorphism, contact metamorphism, and the distribution of granite need further work and would make an interesting study.

\section{STRATIGRAPHY}

The southern two-thirds of the area is composed of three structural blocks, each with somewhat different stratigraphy. In this report, the three areas are designated as follows: the axial zone of the syntaxis inside the bend of the Murree fault, the Garhi Habibullah syncline between the Murree and Panjal faults on the western limb of the syntaxis, and the western arc area west of the Panjal fault. A possible fourth area is west of the Darband fault, but for lack of information it is included in the western arc area.

No single stratigraphic sequence represents the whole area because lateral changes in formations and groups of formations result in different sequences in the different structural areas. Strike-slip and vertical movements along the Murree and Panjal faults probably contributed to the differences between the areas by moving contrasting facies together. Columnar sections showing the stratigraphic correlation between the three structural areas are shown in figure 2. The descriptions of the stratigraphic units are based upon information from all three areas.

The main differences in stratigraphy between the three structural areas may be summarized as follows: (1) The rocks of the Tanawal Formation in the western arc area are absent in the adjacent Garhi Habibullah syncline; and (2) the entire section $(2,000 \mathrm{ft})$ of Jurassic and Cretaceous rocks (Datta Formation-Kawagarh Limestone) in the Garhi Habibullah syncline is absent in the adjacent axial zone of the syntaxis. In one or more of these three areas, regional unconformities are found at the top of the Hazara Formation (Precambrian(?) to Ordovician(?)), the Tanawal Formation (Ordovician(?) to Devonian(?)), and the Kingriali Formation (Carboniferous to Triassic). Within a given structural block, certain rock formations also undergo rapid changes in lithology and thickness from place to place. The regional unconformities and rapid facies changes show that considerable tectonic activity must have taken place in the region long before the Himalayan orogeny, although any such earlier movements did not involve penetrative deformation or metamorphism.

The stratigraphic nomenclature in Hazara has not yet come under study by the Stratigraphic Committee of Pakistan, and therefore the formation names used in this report have not yet been formalized according to the stratigraphic code of Pakistan (Day, 1962). However, the correlation of Jurassic and younger rocks of Hazara has been established with rocks in areas that have been studied and standardized by the committee, and these approved names are used wherever possible. The areas with standardized nomenclature that relate directly to the Hazara region are the Kohat area, the 


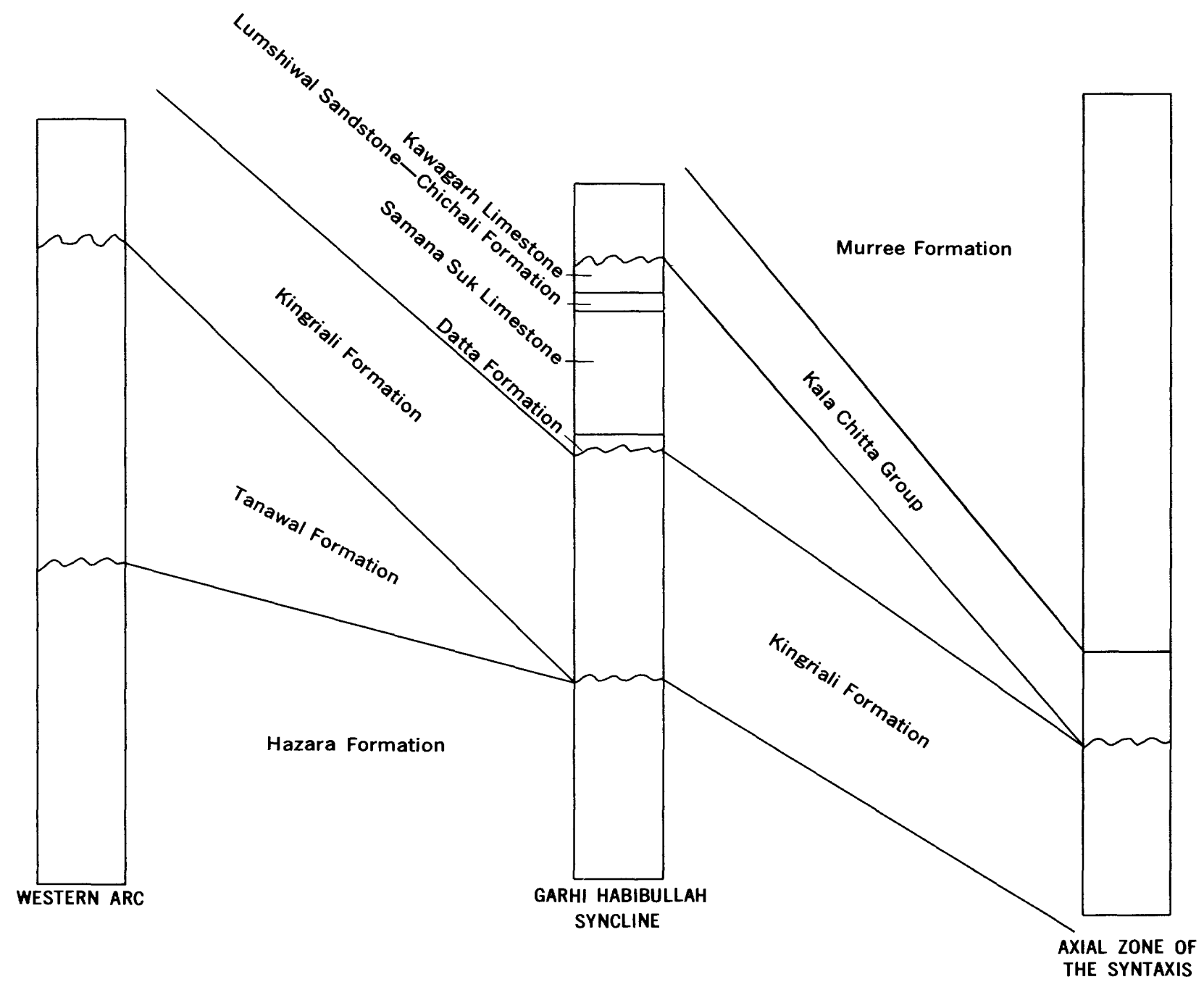

FIGURE 2.-Correlation in the three structural blocks of the southern Hazara area, Pakistan, and part of western Kashmir. Undulating lines represent regional unconformities.

Trans-Indus area, and the Potwar-Kala Chitta area. Correlation charts of these areas in relation to the Hazara region are shown in figure 3.

The formation names of rock units older than Triassic, as used in this report, are names established in previous literature. They may be adopted by the Stratigraphic Committee of Pakistan at some later date or they may be changed.

\section{PRECAMBRIAN TO ORDOVICIAN(?) ROCKS} SALKHALA FORMATION

The oldest known rocks in the Hazara region are the metamorphic rocks of the Salkhala Formation of Precambrian age. These rocks were originally named "Salkhala Series" by Wadia (Pascoe, 1929, p. 154) after Salkhala village on the Kishanganga River, 90 miles east of the mapped area (pl. 1). In the Balakot and Mahandri areas, the unit was called the Salkhala
Formation by Offield and Abdullah (unpub. data, 1965), and it is so called in this report. At the type locality, the Salkhala Formation is overlain by the Dogra Slates (considered equivalent to the Hazara Formation), which in turn are overlain by fossiliferous Cambrian rocks (Fermor, 1931, p. 124). The Salkhala Formation closely resembles the Jutogh Series of Simla (Holland and others, 1956, p. 231).

The Salkhala Formation crops out around the apex of the syntaxis in a belt that widens to several miles in the Mahandri area. Southward, along the west limb of the syntaxis, the unit narrows to only a few hundred feet near Balakot. A second area of outcrops occupies both sides of the Indus River from Tarbela to Kandar. The formation consists largely of quartz schist, marble, graphite schist, and quartzo-feldspathic gneiss. The stratigraphic succession of the individual rock types is not known. 
Quartz schist, which makes up a large proportion of the formation, is mainly fine-grained mica-chloritequartz schist. Chlorite and muscovite make up 20-40 percent of the schist, and the remainder is quartz. Minor amounts of clinozoisite, garnet, magnetite, and biotite are present in places. Calcite or graphite, in laminae and disseminated grains, appears in the schist adjacent to layers of marble or graphite schist.

The marble generally is fine grained and thin bedded and ranges from medium-gray relatively pure calcite marble to dark graphitic marble. Along the Kaghan Road north of Mahandri the marble is white, medium grained, and medium to thick bedded. Some of the marble is highly sheared but not noticeably recrystallized; some is tremolitic. In places along the margins of granite layers, calcsilicate rock has formed by reaction with granite.

The graphite schist is extremely fine grained and sooty and contains 15-25 percent quartz in disseminated minute grains and laminae. Near gradational contacts with marble or schist, it becomes calcareous or micaceous.

The quartzo-feldspathic unit consists of medium- to coarse-grained somewhat gneissic rock made up of quartz, feldspar (microcline and oligoclase), biotite, muscovite, and chlorite. In places it is pegmatitic. The rock has a layered structure and a granitic texture, the texture being modified by foliation and cataclasis. Augen of feldspar are characteristic. Some augen are subhedral crystals as much as $1 \frac{1}{2}$ inches long, but most are less than half an inch long and are rounded and crushed by shearing movements. At Balakot the quartzo-feldspathic unit includes layers or lenses of pure white fine-grained sugary quartzose sandstone and layers of fine-grained gray muscovite-biotitequartz schist, which probably represent argillaceous siltstones. These layers invariably feather out as tenuous stringers into the quartzo-feldspathic gneiss, suggesting that the original beds have been largely replaced (granitized) by the quartzo-feldspathic material. In other places the quartzo-feldspathic rocks resemble an arkosic sediment; perhaps some of the unit represents an original arkosic sandstone.

\section{HAZARA FORMATION}

NAME AND DISTRIBUTION

The various names given to the thick widespread sequence of black and brown slate, phyllite, and littlemetamorphosed graywacke sandstone include "Attock Slates" (Waagen and Wynne, 1872, p. 333); "Slate Series of Hazara" (Middlemiss, 1896); and "Hazara Slate Formation" (Marks and Ali, 1961, p. 48). Because much of the formation consists of rocks other than slate, the name Hazara Formation is considered a more appropriate designation.

The Hazara Formation occupies large parts of an arcuate belt as much as 12 miles wide, which, together with overlying younger rocks, extends southward from the vicinity of Garhi Habibullah through Abbottabad and then westward to Tarbela. In the Attock area, 35 miles southwest of Tarbela, identical rocks are called the Attock Slates.

\section{STRATIGRAPHIC RELATIONS}

In the structural block west of the Panjal fault, the Hazara Formation is overlain unconformably by the Tanawal Formation. East of the Panjal fault, from Abbottabad north to Garhi Habibullah, the Hazara Formation is overlain unconformably by rocks of the Kingriali Formation; the Tanawal Formation is missing. In the apex of the syntaxis, the Hazara Formation is absent, and the Salkhala Formation directly underlies the Tanawal Formation. The thickness of the Hazara Formation is not known, because of isoclinal folding, but its wide outcrop belt implies a great thickness.

\section{LITHOLOGIC DESCRIPTION}

The Hazara Formation consists mainly of slate, phyllite, unmetamorphosed shale, and a few layers of limestone and graphite. Slate and phyllite are dark gray, dark green, or black on the fresh surface and rusty brown or dark green on the weathered surface. Slate units consisting of silt-sized material are somewhat lighter toned than those of clay-sized material, and in places they are crossbedded. Layers of thickbedded fine- to medium-grained graywacke sandstone are found locally, but sandstone is not common.

In the southern part of the mapped area, the equivalent rocks are largely unmetamorphosed shale with silty laminae; only locally are the rocks in the south metamorphosed to slate or phyllite. Most of the argillaceous and silty rocks, whether metamorphosed to slate and phyllite or not, have both bedding and a closely spaced axial-plane cleavage.

Limestone beds totaling as much as 500 feet in thickness and a sequence of calcareous phyllite and gypsum ranging from 100 to 400 feet in thickness are found in two separate zones that extend from Muzaffarabad to Kohala (pl. 4). These beds are gradational with the enclosing slate and phyllite and are an integral part of the Hazara Formation. In the Tarbela area, the Hazara Formation likewise contains a few layers of limestone as well as graphite, graphitic limestone, and calcareous shale.

\section{ORIGIN AND AGE}

The Hazara Formation has been compared with the Alpine flysch, that is a product of deepwater turbidity- 


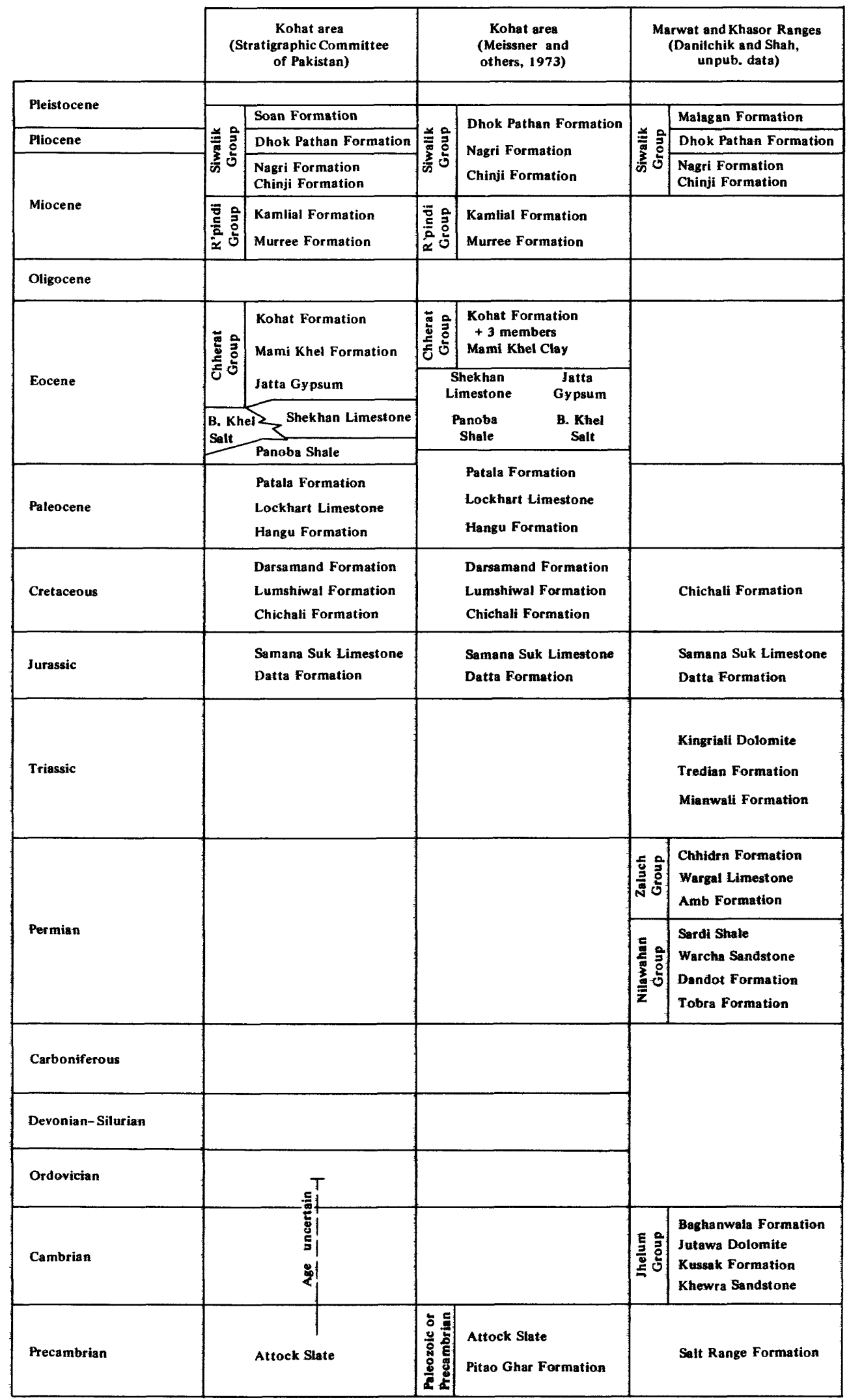

FIGURE 3.-Stratigraphic correlation for 
SOUTHERN HIMALAYA IN HAZARA AND ADJACENT AREAS

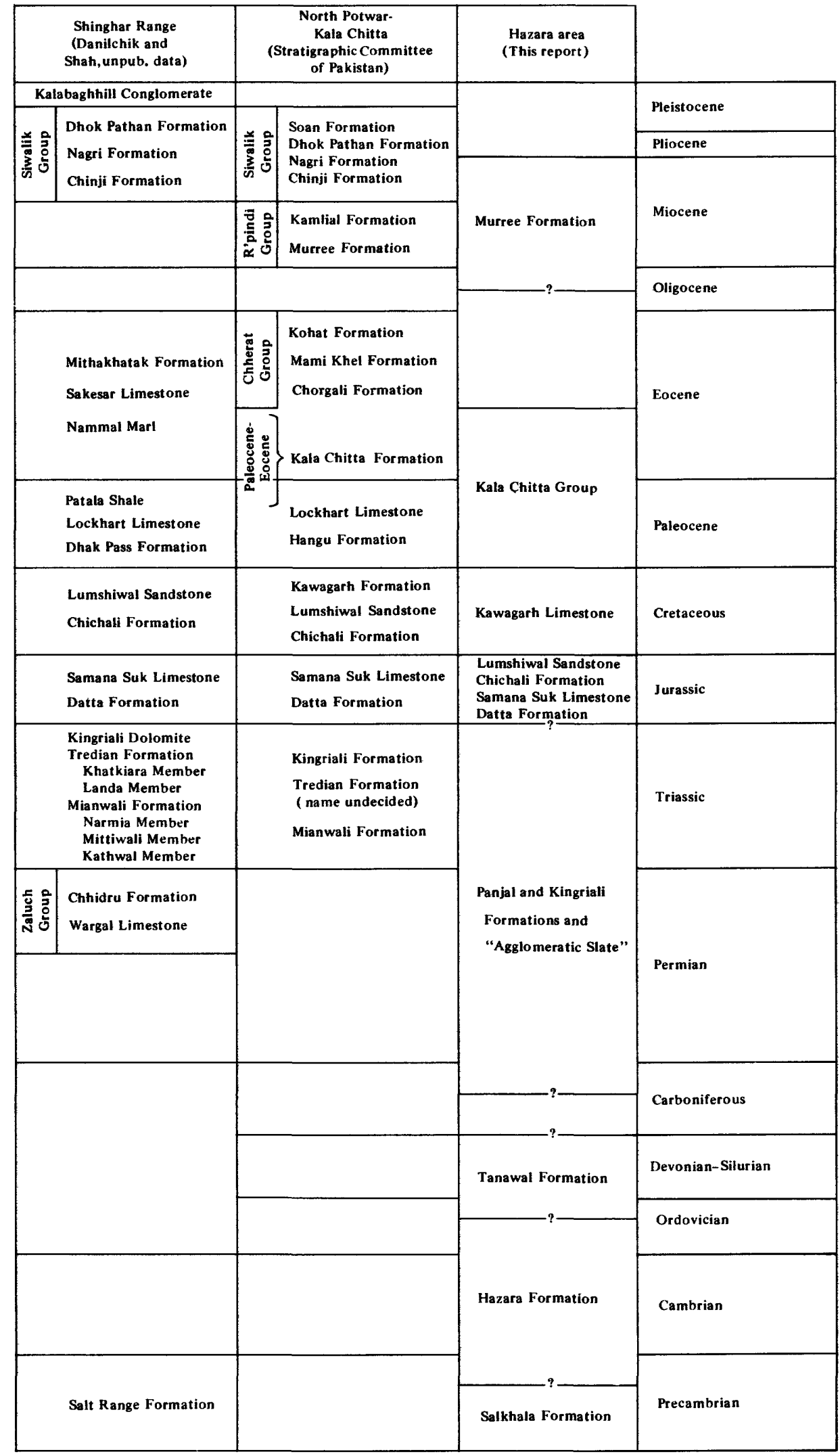

Hazara and other areas of northern Pakistan. 
current deposition (Marks and Ali, 1961, p. 48). However, the presence of limestone, graphite, and even gypsum is unlikely in a turbidite sequence. Most of the formation probably accumulated as a shallow-water argillaceous sequence.

The Hazara Formation probably is equivalent to the Dogra Slates of the Poonch area of Kashmir, which, according to Fermor, are overlain by fossiliferous Cambrian rocks (Fermor, 1931, p. 124). On this basis, the Hazara Formation would be of Precambrian age. However, as no fossils have ever been found, the age of these rocks is uncertain. Their transition into the overlying rocks of the Tanawal Formation, whose lower age limit is possibly Late Ordovician, indicates that the age of the Hazara Formation may extend through the Cambrian and possibly into the Ordovician. The Hazara Formation very likely is equivalent also to the Attock Slates to the southwest and to the Simla Slate Series of India (Holland and others, 1956, p. 18, 240).

\section{ORDOVICIAN(?) TO DEVONIAN(?) ROCKS}

\section{TANAWAL FORMATION}

NAME AND DISTRIBUTION

The Tanawal Formation was originally named "Tanol group" by Wynne $(1879$, p. 122) for a sequence of quartzose schists overlying the Hazara Formation in the area north and east of Tarbella. The term "Tanol" is the name of a former tribal area east of Tarbela where the type area is located. Middlemiss (1896) called these rocks "Tanol quartzites" and believed they formed the lower part of the overlying "Infra Trias" (Kingriali Formation). In a recent paper on the area around Tarbela, the unit is designated "Tanol Formation" (Ali, 1962, p. 32). The name is spelled "Tanawal" in this report, in keeping with current spelling on topographic maps of Pakistan.

The Tanawal Formation is widely distributed over the mapped area, and its outcrop pattern helps to define the general structural trends. The unit occupies wide belts around the southern and southeastern margin of the Mansehra Granite and a narrow belt northward along the western flank of the syntaxis. Metamorphosed rocks considered to be equivalent to the Tanawal Formation occur as inliers within the Mansehra Granite and are widely distributed in the northern part of the area.

\section{STRATIGRAPHIC RELATIONS}

The thickness of the Tanawal Formation is not known with certainty because of the tight folding. Ali (1962, p. 32) estimated this rock unit to be 5,000 feet thick north of Haripur. East of the Panjal fault the
Tanawal Formation is missing, and the Hazara Formation is overlain unconformably by the Kingriali Formation.

In the area between Sherwan and the Indus River, the Tanawal Formation overlies the Hazara Formation and underlies the Kingriali Formation; the lower and upper contacts are unconformable and marked in some places by boulder conglomerate. Between Mansehra and Garhi Habibullah, however, the lower contact is marked only by a lithologic change from slate to quartzite, which in several places is gradational with the underlying Hazara Formation. In the northeastern part of the area, the Tanawal Formation directly overlies the Salkhala Formation unconformably.

\section{LITHOLOGIC DESCRIPTION}

The Tanawal Formation consists mainly of quartzose schist, quartzite, and at places, layers and lenses of quartzose conglomerate. In the Tarbela area, the formation was divided into four units by T. W. Offield, J. A. Calkins, and S. T. Ali (unpub. data, 1965) (this report, pl. 3): conglomerate, lower quartzite, quartz schist, and upper quartzite. The Tanawal Formation is not divided on plate 2 .

South of the Mansehra Granite, where the metamorphic effects are at a minimum, as well as in the Garhi Habibullah area, the Tanawal Formation consists mainly of medium-grained quartzite and thinly laminated fine-grained mica-quartz schist of low to medium metamorphic grade. Various combinations of the main mineral constituents and slight differences in metamorphic grade from place to place result in a variety of rock types. These range from white finegrained quartzose schist, or virtually unmetamorphosed quartzite with very little mica, to dark biotitequartz schist and phyllite containing large amounts of mica. Between these extremes are micaceous quartzite, micaceous quartzose siltstone, brown-weathering spotted biotite-quartz schist, greenish biotite-quartz schist, quartzose muscovite or sericite schist, brown phyllite, and other related rock types. Near the contact with the Hazara Formation east and southeast of Mansehra, the Tanawal Formation consists of alternating layers of mica-quartz schist and black slate, indicating a transitional sedimentary contact. Two miles southeast of Tarbela, schistose conglomerate marks the base of the Tanawal Formation and indicates an unconformable relationship with the Hazara Formation.

Medium-grained quartzite is particularly abundant in the Tarbela area, but fine-grained thinly laminated quartzose schist is also present. The quartzite is well bedded, in layers generally 3-18 inches thick but in places as much as 3 feet thick. Dark-gray phyllite beds and laminae, as well as crossbedding, commonly are 
present. The quartzite is composed mostly of glassy quartz and ranges from fine grained to subconglomeratic; the rock is so well indurated, partly by metamorphism, that it breaks across the grains. It contains 90-95 percent quartz, in subrounded to angular grains, and the remainder of the rock consists of muscovite, magnetite, tourmaline, and feldspar. Brown biotite, indicative of increasing metamorphic grade, is present north of the Sherwan syncline. Tourmaline, which appears black in hand specimen but is green or brown in thin section, is a characteristic accessory of the quartzite.

The ubiquitous presence of accessory tourmaline, and locally of several percent of feldspar, indicates derivation from crystalline source rocks which presumably included granitic material. Although the location of this source area is not definitely known, it is very likely that the source was Precambrian terrane similar to that presently exposed in the Indian Peninsula.

Near the southern margin of the Mansehra Granite and in the vicinity of Mansehra, the Tanawal Formation is characterized by fine-grained thinly laminated rocks which include mica-quartz schist, weakly schistose quartzite, and quartzose siltstone. These alternate with one another to form a layered sequence.

The mica-quartz schist weathers brown, is fine grained, and contains $60-80$ percent quartz and 20-40 percent muscovite and chlorite. Biotite, magnetite, zircon, tourmaline, and garnet are accessories. The fabric in thin sections is generally somewhat cataclastic; crushed quartz forms augen or microaugen along the foliation-bedding surfaces. The quartzite is pale $\tan$ on the fresh surface and weathers very light brown. It is distinguished from the more micaceous laminae by its lighter color and in thin section by its higher quartz content. The siltstone consists of alternating laminae of silt-sized quartz and argillaceous material and is only weakly schistose.

Within the Mansehra Granite and northward in the Battal and Balakot areas, the Tanawal is more highly metamorphosed than it is south of the granite. Garnetbiotite-muscovite-quartz schist as well as andalusite and staurolite-bearing schists form the bulk of the Tanawal Formation in these areas. Proportions of the constituent minerals vary widely. Quartz generally composes 70-90 percent of the schist. Most of the mica is muscovite, but in some rocks only biotite is present. Garnet is ubiquitous, often in porphyroblasts as large as half an inch. Aluminous layers in the more highly metamorphosed parts of the formation are marked by abundant large andalusite or staurolite crystals. Sillimanite also is found in the Radjawari area, and a few layers and lenses of clean hard quartzite also are present in the schist.
AGE

The Tanawal Formation is known only to be younger than the Hazara Formation of Precambrian(?) and possibly early Paleozoic age and older than the Kingriali Formation of Carboniferous to Triassic age. It is tentatively correlated with the Muth Quartzite of Kashmir, 80 miles northeast of Simla in India. The Muth Quartzite has long been considered to be of Silurian to Devonian age. However, recent studies by Boucot and Gauri (1968) indicate that the age of the lower Muth Quartzite is Late Ordovician to Early Silurian, a Late Ordovician age being more likely.

\section{CARBONIFEROUS TO TRIASSIC ROCKS}

\section{KINGRIALI FORMATION}

\section{NAME AND DISTRIBUTION}

The Kingriali Formation was first named Kingriali dolomites by Gee $(1945$, p. 277$)$ for a prominent cliff of dolomite in the Kingriali Hills, 40 miles southwest of Mianwali (pl. 1). In the Hazara area the equivalent dolomite sequence was originally called the "Below the Trias" by Waagen and Wynn, (1872) for the outcrops on Sirban Hill just east of Abbottabad. Middlemiss (1896) modified the term to "Infra Trias," and this term was in common usage in the Hazara area until 1962 when Marks and Ali (1962) proposed the name "Abbottabad Formation." The recent investigations between Hazara and the Afghan border have established the regional distribution of this dolomite sequence, and the Stratigraphic Committee of Pakistan has adopted the name Kingriali Formation for this unit.

The Kingriali Formation occupies parts of the tightly folded belt that extends northeast from Sirban hill, near Abbottabad, to Garhi Habibullah. Other main areas of outcrop include the belts between Sherwan and the Indus River, between Muzaffarabad and Balakot, the Manda Kuchha syncline, and the apex area of the syntaxis.

\section{STRATIGRAPHIC RELATIONS}

In the Sherwan area the Kingriali Formation rests unconformably on the Tanawal Formation. The unconformity is marked in places by boulder conglomerate. Eastward, across the Panjal fault, the underlying Tanawal quartzite is missing, and the Kingriali Formation rests unconformably on the Hazara Formation, the unconformity again being marked by a bed of boulder conglomerate. This conglomerate at the base of the Kingriali Formation is nearly continuous from Abbottabad to Garhi Habibullah.

Rocks younger than the Kingriali Formation are not present in the Sherwan area, but between Abbottabad 
and Garhi Habibullah, the Kingriali Formation is overlain disconformably by the Datta Formation of Early Jurassic age. East of the Murree fault between Muzaffarabad and Balakot, the Kingriali Formation is overlain unconformably by the Kala Chitta Group of Paleocene to Eocene age.

The thickness of the Kingriali Formation varies from place to place. It is about 2,000 feet thick at the type section on Sirban Hill (Marks and Ali, 1961, p. 37), 2,700 feet thick in the Tanal area (Ali, 1962, p. 34-36), 2,500 feet thick in the hills northeast of Muzaffarabad, and only 300-400 feet thick along the east flank of the Garhi Habibullah syncline.

\section{LITHOLOGIC DESCRIPTION}

The Kingriali Formation consists mainly of dolomite, quartzite, and phyllite and their metamorphosed equivalents in the northern part of the area. The stratigraphic order of the dominant rock types varies from place to place, owing to abrupt facies changes and interfingering. As a result, this formation has been divided differently by different workers, depending on the area studied.

The lithologic succession within the Kingriali Fornation in various parts of the Hazara district is illusrated as follows:

\begin{tabular}{|c|c|c|}
\hline $\begin{array}{c}\text { Tarbela area } \\
\text { (T. W. Offield, J. A. } \\
\text { Calkins, and } S . T . \text { Ait, } \\
\text { unpub. data, 1965) }\end{array}$ & $\begin{array}{c}\text { Abbottabad area } \\
\text { (Marks and Ali, 1962) }\end{array}$ & $\begin{array}{c}\text { Muzaffarabad area } \\
(J . A . \text { Calkins and } \\
\text { A. S. A.Matin, } \\
\text { unpub. data, 1965) }\end{array}$ \\
\hline $\begin{array}{l}\text { Upper quartzite } \\
\text { unit. }\end{array}$ & $\begin{array}{l}\text { Upper dolomite } \\
\text { member; } \\
\text { upper shale and } \\
\text { sandstone member. }\end{array}$ & Dolomite unit. \\
\hline Dolomite unit. & $\begin{array}{l}\text { Lower dolomite } \\
\text { member. }\end{array}$ & Limestone unit. \\
\hline $\begin{array}{l}\text { Lower quartzite } \\
\text { unit. }\end{array}$ & $\begin{array}{l}\text { Lower shale and } \\
\text { sandstone member. }\end{array}$ & Dolomite unit. \\
\hline $\begin{array}{l}\text { Phyllite unit } \\
\text { (conglomerate in } \\
\text { part). }\end{array}$ & $\begin{array}{l}\text { Basal conglomerate } \\
\text { member. }\end{array}$ & $\begin{array}{l}\text { Quartzose sandstone } \\
\text { and basal con- } \\
\text { glomerate unit. }\end{array}$ \\
\hline
\end{tabular}

The dolomite and the basal conglomerate or phyllite have wide lateral distribution. The other units are local in extent.

In the Tarbela area the phyllite unit is persistent but thin; the other three members vary considerably in thickness at the expense of one another in very short distances. These abrupt facies changes are well illustrated on the geologic map of the Sherwan area (J. A. Calkins, T. W. Offield, and S. T. Ali, unpub. data). The dolomite unit, for example, which is at least 1,000 feet thick on the north flank of the syncline, is missing along part of the south flank, its place having been taken by quartzite. West of the Siran River, the dolomite on the south flank of the syncline becomes thick again at the expense of the quartzite.

The phyllite unit forms the base of the Kingriali Formation nearly everywhere in the Tarbela area. This unit was called the "basal conglomerate member" by Ali $(1962$, p. 34). It is a gray- and brown-weathering phyllitic sequence of shale and siltstone; lenses of conglomerate are scattered through the unit and commonly mark the base of the unit but are not restricted to it. In places there is no conglomerate at the base. Pebbles and cobbles in the conglomerate consist mainly of Tanawal quartzite but also include phyllite, shale, and vein quartz.

The upper and lower quartzite units of the Tarbela area are quite similar in lithologic character and were separated only on the basis of the intervening dolomite unit. The upper quartzite unit is shown separately on plate 2 . The quartzite units are thin to medium bedded and generally conspicuously crossbedded. The rock ranges from even-textured fine-grained quartzite to subconglomeratic quartzite containing abundant coarse glassy or milky quartz granules and small fragments of phyllite. In texture and bedding characteristics, this quartzite is much like that of the Tanawal Formation but is distinguished by its typical red, reddish-gray, or even black color and absence of phyllite partings.

The dolomite unit of the Tarbela area consists of dark-weathering interlayered brown and gray microcrystalline dolomite. It is thin to thick bedded and commonly cherty, and in places rounded sand-sized quartz grains are scattered throughout the rock. The brown dolomite contains veins of coarsely crystalline ankerite. Intercalations of black phyllite and quartzose sandstone are common, as well as partially dolomitized gray limestone in which dolomite is distributed in patchy fashion parallel to the bedding in the limestone. The presence of dolomitized limestone shows that at least some of the dolomite is secondary, but whether all the dolomite is secondary is not known. In the Sherwan syncline, distinct layers of undolomitized gray limestone are present within the dolomite.

In the outcrop belts between Abbottabad and Garhi Habibûllah and between Muzzaffarabad and Balakot, the Kingriali Formation consists primarily of cherty dolomite with quartzite and conglomerate at the base of the formation. The dolomite is gray to white on the weathered surface and dark gray to black on the fresh surface. Some layers are distinctly pink, possibly owing to the presence of manganese carbonate. Beds range in thickness from thin laminations to 2 feet. Locally, beds of intraformational conglomerate and quartzose sandstone are found, and D. F. Davidson, U.S. Geological 
Survey (oral commun., 1971), noted a bed of phosphorite half a mile north of Kakul. Chert, which stands out in relief on the weathered surfaces, is distributed in layers, lenses, and irregular patches; the chert layers are as much as $\mathbf{1 0 0}$ feet long. Because of its silica content, the dolomite is extremely brittle and is traversed by many closely spaced open joints. For hundreds of feet away from a fault, the dolomite is shattered into small cubes which collect into huge talus cones at the base of steep slopes.

Between Abbottabad and Garhi Habibullah, the base of the formation is marked by a conglomerate overlain by red and white quartzose sandstone and siltstone. In the Garhi Habibullah area, these basal rocks were mapped as a separate member (pl. 4), whose total thickness ranges from 100 to 600 feet. The conglomerate bed itself, although only a few feet to 50 feet thick, is quite persistent. Between Chure Gali and Kalapani, most of the Kingriali Formation is missing, and only these basal rocks are present. The conglomerate marks the angular unconformity between the Kingriali Formation and the underlying Hazara Formation. It consists of flat elongate fragments of slate, phyllite, siltstone, or graywacke sandstone ranging from 1 inch to 2 feet long in a chloritic phyllite matrix.

One mile south of Garhi Habibullah on the east side of the Kunhar River, the basal unit of the Kingriali Formation, in addition to the usual boulder conglomerate and quartzose rocks, contains brown phyllite interbedded with the quartzose beds. The presence of phyllite within the basal unit of the Kingriali Formation shows that the metamorphism is post-Kingriali Formation in age.

In the outcrop area between Muzaffarabad and Balakot, a distinctive interval of black limestone and black calcareous shale 400-450 feet thick is found near the top of the Kingriali Formation. It is shown as a separate unit in the Garhi Habibullah quadrangle (pl. 4) but is not separated on plate 2 .

In the northern, more highly metamorphosed part of the area, dolomite and calcite marble, and associated quartzite, are assigned to the Kingriali Formation on the basis of comparable lithology and general stratigraphic position.

In the Manda Kuchha syncline and in the outcrop belt between the Paras and Sharan faults, the Kingriali Formation interfingers with volcanic greenstone of the Panjal Formation. Limestone considered by Wadia (1931, p. 210-212) to be of Triassic age also is associated with the Kingriali Formation east of Paras.

The marble of the Kingriali Formation is generally laminated or thin bedded and white, gray, or blue. It is siliceous in many places, and near Manda Kuchha it is interbedded with quartzite. Phlogopite and chlorite are common accessory minerals; in a few places the marble contains clots or radiating clusters of tremolite. Between the Paras and Sharan faults, the dolomite and quartzite are essentially unmetamorphosed, although the associated volcanic rocks are foliated greenstone units.

The quartzite units in the Manda Kuchha syncline are thin bedded, tan or snow white, and weather to white kaolinitic quartz sand by solution of the carbonate cement. In places, the weathered surface is slightly iron stained. The quartzose rocks look like unmetamorphosed quartz sandstone, the only indication of metamorphism being the presence of phlogopite and biotite mica along the well-marked bedding planes. Petrographically the quartzites are fine- to mediumgrained phlogopite-biotite-calcite-quartz granulites. Quartz in clear angular grains composes 60-95 percent of the rock; carbonate, in recrystallized discrete angular grains, makes up most of the remainder. Micas and feldspar are present in small amounts. Recrystallization of the original quartz grains is shown by their sharply angular fit against carbonate grains and against each other and by partially developed idiomorphic boundaries. Carbonate material, which probably constituted the original cement, is part calcite, part dolomite, the latter being indicated by lack of effervescence in the hand specimen when treated with cold dilute acid.

\section{AGE AND CORRELATION}

The age of the Kingriali Formation is uncertain. The formation overlies the Tanawal Formation of Ordovician(?) to Devonian(?) age and underlies the Datta Formation of Early Jurassic age. In the Balakot and Mahandri areas, the Kingriali Formation is interbedded with rocks of the Panjal Formation, which farther east in Kashmir contains a Carboniferous to Permian fauna (Holland and others, 1956, p. 8). However, Curt Teichert (Univ. of Kansas, written commun., 1965) reported that west of the Indus, rocks of similar lithology and stratigraphic position contain conodonts no younger than Late Devonian.

Information on the age of the Kingriali Formation, which is more closely related to the Hazara area, was given by A. N. Fatmi (Geol. Survey Pakistan, written commun., 1964), who reported Early Jurassic ammonites from the Datta Formation of the Kala Chitta Hills 60 miles southwest of Abbottabad. The Kingriali Formation, which underlies the Datta Formation, is therefore pre-Early Jurassic in age.

On the basis of the present conflicting information, the Kingriali Formation is tentatively assigned a Carboniferous to Triassic age. It may be equivalent to the Swabi Formation west of the Indus (Martin and others, 1962, p. 6-7). 


\section{PANJAL FORMATION}

NAME

A belt of volcanic greenstone and agglomeratic rocks that wraps around the apex of the syntaxis consists of two stratigraphic units: agglomeratic rocks, called "Agglomeratic Slate" by Middlemiss (1910, p. 232), and a thick and extensive sequence of volcanic greenstone which was named the Panjal System by Lydekker $(1878$, p. 34$)$. The volcanic greenstone also has been called the "Panjal traps" and "Panjal volcanics." The word "Panjal" comes from the Pir Panjal Range in Kashmir, 50 miles southeast of the Hazara area, where the sequence is well developed. Wadia (1931, p. 208) combined the volcanic greenstone and agglomeratic slate into one unit called the "Panjal volcanic series." In this report, the Panjal volcanic series of Wadia is called the Panjal Formation. The volcanic greenstone and agglomeratic slate are mapped as separate units of the Panjal Formation but are discussed together in the following paragraphs.

\section{LITHOLOGIC DESCRIPTION}

Wadia (1931, p. 210) estimated the combined thickness of the formations at Paras to be more than 9,000 feet. This figure probably is too large, however, because the sequence is repeated by folding and faulting.

The agglomeratic rocks consist of black carboniferous slate or shale, glassy quartzose agglomeratic sandstone, and small amounts of phyllite and conglomeratic sandstone. The agglomeratic sandstone contains angular fragments of volcanic rock, white quartz, gray slate, and brown dolomite in a sand-sized matrix of fine- to medium-grained quartz and muscovite. A few layers of porous glassy tuff were seen. Regional metamorphism is indicated by the ubiquitous sutured boundaries of quartz grains and rock fragments and by the recrystallized texture of muscovite. Porphyroblasts of andalusite, now completely changed to sericite, are found in a few places in the Mahandri area. This change is likely due to retrogressive metamorphism upon cooling.

Closely associated with the agglomeratic rocks is the volcanic greenstone of the Panjal Formation. This rock consists of metamorphosed lava flows and tuffs of intermediate to mafic composition. It is light green to brown to bright green and contains chlorite, epidote, and feldspar as the main mineral constituents. In many of the layers, conspicuous dark-green blebs of chlorite scattered throughout give the rock a spotted appearance, and this rock is considered to be composed of tuffs. Muscovite is present instead of chlorite in some rocks. Greenstones with original amygdules still preserved are interbedded with tuffs and are identified as metamorphosed lava flows. The groundmass of the flows consists of chlorite, muscovite, plagioclase, and magnetite. In a few specimens the shapes of the original plagioclase and pyroxene crystals can be seen. The amygdules, in many instances smeared out to form flat oval blebs, are filled with chlorite, epidote, or quartz.

The volcanic greenstone generally has a weakly developed schistosity, in most places parallel to original layering. The chlorite blebs, amygdules, and other textural elements tend to be alined and stretched to form a prominent lineation.

Amphibolite, considered to be a more highly metamorphosed representative of the Panjal volcanic rocks, occupies much of the Manda Kuchha syncline. The amphibolite is well foliated, and the foliation seems to be parallel to the original layering and to define the synclinal structure. The amphibolite rocks are fine to medium grained and are composed of variable proportions of bright-green hornblende, plagioclase, clinozoisite, and biotite, together with the accessories magnetite and sphene. The lath-shaped minerals are generally oriented in planes and help define the layered structure, but seldom do they show a preferred orientation within these planes. Some layers are marked by round or oval clots of granulated plagioclase, which probably represent original phenocrysts in a porphyritic mafic lava flow. Relict diabasic, gabbroic, and amygdaloidal textures are also seen, and these features indicate that the amphibolite represents original lava flows perhaps locally intruded by small plugs of coarser mafic rock.

\section{AGE}

The age of the Panjal Formation ranges from Carboniferous to Permian in western Kashmir to Triassic in eastern Kashmir. In western Kashmir, the Panjal Formation contains fossils of late Carboniferous to Permian age (Holland and others, 1956, p. 8).

\section{JURASSIC ROCKS}

\section{DATTA FORMATION}

\section{NAME AND DISTRIBUTION}

The name Datta Formation was given by Walter Danilchik and S. M. I. Shah (unpub. data) to the sequence of sandstone and red shale in Datta Nala in the Shinghar Range near Kalabagh. This same unit occupies parts of the Kohat area (Meissner and others, 1973), the Dera Ismail Khan area (Hemphill and Kidwai, 1973), the Kala Chitta Hills, and the Hazara area of this report.

In the Hazara area, the Datta Formation forms a thin but highly persistent sequence of red and brown shale and quartzose sandstone beds that crop out in the tightly folded belt east and northeast of Abbotta- 
bad. In places, these rocks contain low-grade sedimentary iron ore, and for purposes of economic investigation a detailed study was made of these rocks using a special large-scale base map, which is reproduced as plate 5. From the geologic point of view, this detailed study of the Datta Formation and associated rocks furmished the key to the stratigraphy and complex structure northeast of Abbottabad, which in turn provided important information relative to the development of the west limb of the syntaxis.

The rocks of the Datta Formation were first observed on Sirban Hill near Abbottabad by Waagen and Wynne $(1872$, p. 336$)$, who included them in the upper part of their "Below the Trias" group (Kingriali Formation). Sirban Hill is along the southward continuation of the tightly folded belt shown on plate 5 , but it has not been mapped in detail.

\section{STRATIGRAPHIC RELATIONS}

The Datta Formation is between the Samana Suk Limestone and the Kingriali Formation; the upper and lower contacts are disconformable. Because of the many strike faults, the Datta Formation is missing in many places. In the Galdanian and Chure Gali areas the formation ranges in thickness from 90 to 160 feet, but westward near the Panjal fault the thickness exceeds 500 feet. On plates 4 and 5 the Datta Formation is divided into an upper quartzose sandstone unit, a middle shale unit, and a lower quartzose sandstone unit. On the regional map this formation is shown as a single unit.

\section{LITHOLOGIC DESCRIPTION}

The upper and lower units of the Datta Formation both consist of well-cemented medium- to fine-grained quartzose sandstone. In general, bedding is well defined, but crossbedding is rare. In most cases the rock is white, but in some instances it is red, because of layers of red shale and staining by iron oxide.

The middle unit of the Datta Formation consists of iron-rich beds in the Kakul, Galdanian, and Chure Gali areas, but it changes to brown shale along the western belt of outcrops. In the Kakul-Galdanian area, the middle unit consists of red hematitic claystone and siltstone and a few layers and lenses of black massive hematite and black manganese oxides. Some of the claystone contains a high percentage of hematite. The rocks have several kinds of primary sedimentary structures, including oolites, pellets, and nodules.

In the Chure Gali area the middle unit retains its red color but contains less hematite and relatively more tan and gray claystone. Near Chure Gali this unit has numerous lenses of black manganese oxide near the top, some as much as 1,200 feet long.
The middle unit nearly everywhere is bounded above and below by red and white quartzose sandstone and siltstone. The thickness of these sandstone units ranges from a few feet to several hundred feet.

\section{AGE}

The Datta Formation is Early Jurassic in age; it was dated on the basis of Early Jurassic ammonites found by A. N. Fatmi (Geol. Survey Pakistan, written commun., 1964) in the same unit in the nearby Kala Chitta Hills.

\section{SAMANA SUK LIMESTONE}

\section{NAME AND DISTRIBUTION}

The name Samana Suk Limestone was given by Davies $(1930$, p. 3) to a sequence of dark-gray limestone of Jurassic age in the east-central part of the Parachinar area, 50 miles west of Kohat (Meissner and others, 1973). This formation extends southward to Dera Ismail Khan (Hemphill and Kidwai, 1973) and eastward through Kohat and the Kala Chitta Hills, as far as the Hazara area.

In the Hazara region, the Samana Suk Limestone underlies Daulatmar Peak and parts of the area between Abbottabad and Garhi Habibullah.

\section{STRATIGRAPHIC RELATIONS AND LITHOLOGY}

Because of the intensity of folding, the thickness of the Samana Suk Limestone is uncertain. One section measured by A. N. Fatmi (Geol. Survey Pakistan), 2 miles north of Kalapani, had a minimum thickness of 1,100 feet.

The Samana Suk Limestone is in disconformable contact with the underlying Datta Formation. The upper contact everywhere is a shear zone resulting from the intense squeezing of the overlying Chichali Shale.

The Samana Suk Limestone is essentially clastic. The rocks are black to dark-gray thick-bedded limestone that weathers light gray and commonly is crossbedded. Petrographically, the most common rock is a fine-grained pelletal limestone which has a matrix of microcrystalline ooze. Comminuted shell debris is present in varying amounts, and in some layers is abundant enough for the rock to be considered biogenic limestone. Some of the rocks are distinctly oolitic. Sparry cement (clear calcite) makes up only a small part of the matrix, but clear calcite is also present as secondary fillings in cracks. Incipient dolomitization has taken place in a few irregular patches along certain bedding planes.

\section{AGE AND CORRELATION}

Limestone of Jurassic age is found throughout the western mountainous belt of Pakistan. A probable 
equivalent to the Samana Suk Limestone is the Sulaiman Limestone Group of the Sulaiman Range (Hemphill and Kidwai, 1973), and in the Quetta area the limestone is known as the Takatu Limestone, after Takatu Peak near Quetta, and the Chiltan Limestone, after Mount Chiltan southwest of Quetta. Initial study of fossil specimens indicates that the Samana Suk Limestone is Jurassic in age. A written communication by J. Harlan Johnson (1963), Colorado School of Mines, on thin sections containing dasycladaceous algae is quoted in part as follows: "Two of the Pakistan slides contain fairly well preserved fragments of Dasyclad algae ${ }^{* * *}$ these turn out to be new and undescribed species, possibly even a new genus. However, the genus is very close to one described years ago by Yabe, which he named Neogyroporella. So far, this has been reported only from beds of Late Jurassic and earliest, i.e., pre-Aptian Cretaceous."

A Cretaceous age is ruled out, inasmuch as the Samana Suk Limestone is overlain by Upper Jurassic rocks (Chichali Formation). Therefore, the Samana Suk Limestone is considered to be of Jurassic age.

\section{JURASSIC TO CRETACEOUS ROCKS}

\section{CHICHALI FORMATION AND LUMSHIWAL SANDSTONE}

\section{NAME AND DISTRIBUTION}

The Chichali Formation (Upper Jurassic) and Lumshiwal Sandstone (Upper Jurassic to Lower Cretaceous) have widespread distribution in Pakistan, including the Dera Ismail Khan area through the Kalabagh, Kohat, and Kala Chitta Hills areas, to Hazara. In the Great Himalaya range, stretching across northwestern India and Kashmir, the equivalent formations are known as the Spiti Shale and Giumal Sandstone, both so named long ago by Stoliczka (1865, p. 85,113 ).

The Chichali Formation was named by Walter Danilchik and S. M. I. Shah (unpub. data) for outcrops of glauconitic sandstone in Chichali Nala near Kalabagh, which is the type area. It was formerly known as the "Belemnite Beds" (Oldham, 1892, p. 19). The Lumshiwal Sandstone, which overlies the Chichali Formation, was named by Gee (1945) after Lumshiwal Nala in the Surghar Range near Makarwal.

The Chichali Formation and the Lumshiwal Sandstone are discussed together in this report because they are not very thick in the Hazara area. In the Spiti area of India, these two units have a combined thickness of more than 1,000 feet, but in Hazara their combined thickness in many places is as little as $\mathbf{1 5 0}$ feet.

The Chichali Formation and Lumshiwal Sandstone form narrow outcrop bands extending northward from the vicinity of Kalapani to a point about 1 mile south- west of Chure Gali. They lie between Lower Jurassic limestone and Upper Cretaceous limestone. The two units taken together make an excellent marker horizon because of their lithologic contrast to the adjacent limestone, and they, together with the Datta Formation, provide the key to the tightly folded structure shown in detail on plates 4 and 5 .

\section{STRATIGRAPHIC RELATIONS AND LITHOLOGY}

In Hazara, the Chichali Formation ranges from a few feet to 300 feet in thickness and consists entirely of soft thinly laminated highly organic black shale. Because of its incompetent nature, it has been thoroughly squeezed and contorted so that the upper and lower contacts are everywhere sheared. The Chichali Formation in Hazara actually is more closely related to the Spiti Shale of India than to the outcrops at the type area, which are composed mainly of glauconitic sandstone containing belemnites. However, the name Spiti Shale has been dropped by the Stratigraphic Committee of Pakistan, and the name Chichali Formation extended to include the outcrops of Spiti Shale in Hazara.

The Lumshiwal Sandstone, which is $10-50$ feet thick, overlies the Chichali shale, and the contact with the Kawagarh Limestone above it is a 4-foot gradational zone. It consists of rounded quartz grains and minor glauconite in a black calcareous matrix. The rock is medium grained, soft, friable, and very calcareous, the calcareous matrix making up about half the rock. A 3to 5 -foot interval at the base contains abundant belemnites. Fresh surfaces are black, but the rock weathers to a distinctive brownish orange.

\section{AGE}

The Chichali Formation is Late Jurassic in age as determined from ammonites collected near Abbottabad by Waagen and Wynne (1872) and more recently by Ahmad (1961, p. 66), who identified Perisphinctes frequens and Belemnopsis canaliculatus. Further west the Chichali Formation is reported to be Early Cretaceous in age (Spath, 1939, p. 117; Meissner and others, 1973; Hemphill and Kidwai, 1973; Walter Danilchik and S. M. I. Shah, unpub. data). In the Kala Chitta Hills, halfway between the western area and Hazara, A. N. Fatmi, Geological Survey of Pakistan, considered the Chichali Formation to be of Late Jurassic age (oral commun., 1963). Evidently the formation undergoes a slight time transgression from Late Jurassic age in the east to Early Cretaceous age in the west.

The Lumshiwal Sandstone in Hazara is Late Jurassic to Early Cretaceous in age on the basis of ammonites collected from several localities in the area by $A$. N. 
Fatmi and Calkins and by members of Panjab University (Marks and Ahmad, 1962, p. 54; Ahmad, 1961, p. 66). Several well-preserved ammonites figured by Fatmi in the Kalapani area include Virgatosphinctoides and Aulacosphinctoides, both of Late Jurassic age, and Brancoceras, Subthurmannia, and Lyelliceras, all of Early Cretaceous age.

\section{CRETACEOUS ROCKS}

\section{KAWAGARH LIMESTONE}

\section{NAME AND DISTRIBUTION}

The name Kawagarh Limestone was proposed by A. E. Day (Attock Oil Co., written commun., 1968) for the Upper Cretaceous limestone exposed in the Kawagarh Hills and other parts of the Potwar-Kala Chitta Hills area. In this report, Kawagarh Limestone is used instead of Kawagarh Formation. Cretaceous limestone was noted in the Hazara area as early as 1872 by Waagen and Wynne (1872, p. 342), but the rocks have never been named or mapped as a separate unit. The Kawagarh Limestone forms a belt of outcrops extending southward from about 1 mile north of Sattu to the south edge of the mapped area near Abbottabad. The limestone occupies the center of a south-plunging synclinal structure which extends southward to Kakul. Excellent exposures are seen on the high ridge north of Sattu and along the steep trail from Sattu towards Galdanian. On the steep north-facing slopes and in the deep canyon just north of Sattu, however, the outcrops are completely obscured by heavy timber and dense brush. Because of the lithologic similarity between the Kawagarh Limestone and the Samana Suk Limestone, some of the rocks of the Samana Suk Limestone may be included with the Kawagarh Limestone.

\section{STRATIGRAPHIC RELATIONS AND LITHOLOGY}

The Kawagarh Limestone is about 350 feet thick in the mapped area. Along the eastern limb of the syncline, the Kawagarh Limestone rests conformably on the Lumshiwal Sandstone. The west limb of the syncline is faulted. At the northern end of the syncline, the exact location of the Kawagarh Limestone can only be inferred because of the heavy timber and dense brush in this part of the area. In the Kakul-Kalapani area, the Kawagarh Limestone is overlain disconformably by the Kala Chitta Group, the contact commonly marked by a zone of laterite.

The Kawagarh Limestone is light gray, thick and thin bedded, and has a fine, even-grained, nearly lithographic texture. Pellets, oolites, fossil debris, and other clasts are not visible megascopically, although in certain rare clastic layers, minute brownish oolites can be seen. The limestone commonly is stained in shades of brown or red because of the presence of limonite and siderite in veins, nodules, and along bedding planes and joints.

Because of its similarity to the Jurassic limestone, the main clues to the recognition of the Kawagarh Limestone are that it rests on top of the Lumshiwal Sandstone of Jurassic to Cretaceous age and that it contains a distinctive Foraminifera (Globotruncana), visible in the hand specimen. However, certain other features help in a general way to distinguish the Kawagarh Limestone from the Samana Suk limestone.

The following summary shows the main characteristics of both limestone formations, which, although not mutually exclusive, serve to separate the two units:
Kawagarh Limestone

\section{Dark gray}

2. Visibly clastic; clasts mainly pellets and fossil debris

3. Crossbedding common

4. Red and brown stain rare
Samana Sulc Limestone

1. Light gray

2. Dense, fine-grained; clastic layers are rare

3. Crossbedding rare

4. Red and brown stain common

5. Contains Globotruncana, visible in the hand specimen

\section{AGE AND CORRELATION}

The assignment of a Late Cretaceous age to the Kawagarh Limestone is based on the presence of the Foraminifera Globotruncana, visible in the hand specimen, and on the fact that the unit overlies the Lumshiwal Sandstone of Late Jurassic to Early Cretaceous age. Specimens of rare bioclastic layers and a few wellpreserved corals are under study, but the results are not yet available. Latif (1962) reported that Foraminifera of Late Cretaceous age, including Globotruncana, Heterohelix, Rugoglobigerina, and Pseudotextularia have been found in the Kawagarh Limestone. The Kawagarh Limestone probably is equivalent to the Chikkim Limestone of the Spiti area in India (Stoliczka, 1865), and according to Latif (1962), it may be equivalent to the Parh Limestone of Baluchistan. The formation also is equivalent to the Darsamand Limestone of the Kohat area.

\section{TERTIARY ROCKS}

\section{KALA CHITTA GROUP}

\section{NAME AND DISTRIBUTION}

The rocks of early Tertiary age forming the Kala Chitta Group in Hazara were known for many years as the "Nummulitic Formation," so named long ago by Waagen and Wynne (1872, p. 343) for outcrops of foraminiferal limestone and calcareous shale on Sirbon Hill near Abbottabad. 
The name Kala Chitta Group was proposed by N. A. Bhatti (Geol. Survey Pakistan, written commun., 1968) for the sequence of limestone and calcareous shale of Paleocene to Eocene age in the Kala Chitta and Potwar areas. This group, which comprises several formations of variable thickness and extent, is essentially a marine sequence, and as proposed, it would separate the lower Tertiary marine sequence from the alternating marine and nonmarine strata composing the Chherat Group above it. (See fig. 3.) However, the Stratigraphic Committee of Pakistan (written commun., Apr. 1969) has recommended that the term Kala Chitta Group be dropped and that the rocks within this group be defined only in terms of the three individual formations that make up the Kala Chitta Group. As shown in figure 3, the Stratigraphic Committee would retain a group name (Chherat Group) for the upper three formations but would drop the name Kala Chitta Group for the lower three formations. In the mapped area it was not feasible to divide this limestone-shale sequence into separate formations, and therefore the name Kala Chitta Group is used here to define the Paleocene to Eocene rocks in this map area. It seems desirable that the term Kala Chitta Group be retained for use in cases when the level of stratigraphic refinement called for by the Stratigraphic Committee is not needed or cannot be achieved.

The Kala Chitta Group occupies two main parts of the mapped area of this report: the first is a nearly continuous belt extending from a point 2 miles east of Muzaffarabad northwestward to Balakot, and the second is just east of Abbottabad. A few outcrops also are seen on the Pakistan-Kashmir divide in the axial zone of the syntaxis. Rocks of this unit also are found in the troughs of synclines in the Nathia Gali area, but this area is unmapped.

\section{STRATIGRAPHIC RELATIONS AND LITHOLOGY}

The thickness of the Kala Chitta Group is about 1,300 feet where it crosses the Kishanganga River and about 2,000 feet on the high ridge north of Sirikot. Northwest of Sirikot toward Balakot the formation thins rapidly to 150 feet. In this belt (Kishanganga River to Balakot) the Kala Chitta Group is conformable and transitional with the overlying Murree Formation and rests unconformably on the Kingriali Formation, although in many places this lower contact is also a fault of small displacement. In the Kakul area the Kala Chitta Group rests disconformably on the Kawagarh Limestone, the disconformity being marked by a laterite zone.

The greater part of the Kala Chitta Group consists of gray poorly bedded generally nodular limestone and dark-gray calcareous shale. The shale commonly contains nodules of clayey limestone. Some of the beds are, to a large degree, bioclastic, containing abundant fossils, especially Foraminifera.

In the Muzaffarabad area the base of the unit is marked by a zone of quartzose sandstone, high-alumina blue-gray shale, in places pisolitic, and black carbonaceous shale which is coal bearing. One or another of these three lithologic types is everywhere present at the base of the Kala Chitta Group in the Muzaffarabad area, even toward the north where the formation thins markedly. This lithology is similar to that of the Hangu Formation of the Kohat area (Meissner and others, 1973). The presence of these basal rock types strengthens the conclusion that the contact with the underlying Kingriali Formation is an unconformity, even though this contact in many places is sheared.

\section{AGE AND CORRELATION}

The Kala Chitta Group is Paleocene to Eocene in age. The formation is equivalent to the Patala and Hangu Formations and the Lockhart Limestone (Paleocene) of the Kohat area (C. R. Meissner, written commun., 1963) and to the Kirthar Limestone (Eocene) of the Quetta-Baluchistan region (E. B. Fritz, oral commun., 1963). Foraminifera collected from the Chhalpani village and identified by E. B. Fritz, U.S. Geological Survey, include the following genera: Operculina and Miscellanea of Paleocene age and Lepidocyclina, Lockhartia, Alveolina, and Assilina of Eocene age. Rock specimens collected from a locality near Muzaffarabad by Curt Teichert, University of Kansas, contained corals, Hydrozoa, and Foraminifera.

\section{MURREE FORMATION}

\section{NAME AND DISTRIBUTION}

Wynne $(1874$, p. 66) recorded the first name for the widespread sequence of red shale and sandstone of Tertiary age found along the foothills of the Himalaya. He called these rocks the "Mari Group" after the "Mari Hill Station" 35 miles northeast of Rawalpindi. "Mari" is now spelled Murree. Subsequent designations for this sequence have been "Murree beds" (Lydekker, 1876) and "Murree Series" (Pilgrim, 1910; Wadia, 1928 , p. 268). The unit is now called the Murree Formation by the Geological Survey of Pakistan. It has been divided into two units by other workers but is considered only as one unit in this report.

In the mapped area the Murree Formation is found only in the axial zone of the syntaxis, but the unit is known to extend for hundreds of miles to the east and 
west. Equivalent beds at Simla are called the Kagshai and Kasauli Series (Holland and others, 1956, p. 174).

\section{STRATIGRAPHIC RELATIONS AND LITHOLOGY}

The thickness of the Murree Formation is uncertain because of tight folding in the region. Wadia (1928, p. 269) estimated a thickness of 6,000 feet. On the spur east of Lachi Khan, 8 miles north of Muzaffarabad (pl. 4), an undisturbed section totaling 5,000 feet could be seen. In the International Stratigraphic Lexicon (Holland and others, 1956) the formation is estimated as more than 8,000 feet thick. The lower contact is gradational into the underlying Kala Chitta Group. The transition zone, which consists of beds of marl alternating with green and red shale, ranges in thickness from 60 feet along the Kishanganga at Chhalpani to 2,000 feet on the high ridge north of Sirikot. The upper contact is nowhere exposed in the map area, but southward the Murree Formation is overlain conformably by the "Siwalik Series" (Wadia, 1928, p. 269-270).

The Murree Formation consists of red thinly laminated siltstone and shale, thick-bedded red mudstone, and subordinate green, gray, and maroon fine- to medium-grained graywacke. Most of the Murree contains enough interstitial carbonate to effervesce in dilute acid. Graywacke forms beds $2-20$ feet thick, which commonly are crossbedded. In places, the graywacke beds are lenses ranging in length from 100 to 300 feet and in width from 2 to 10 feet. Beds of calcareous sandy conglomerate in places are intercalated with the sandstone. The pebbles are calcareous, and although most of them are oval, many are flattened and squeezed into various shapes, some even tapering to a point on one end. Evidently these pebbles originally were soft calcareous mud balls formed at the site of deposition rather than being transported detritus.

The sandstone consists of remarkably angular sandsized grains of chert, quartz, volcanic rock fragments, and feldspar (mostly oligoclase). Chert and quartz make up about 60 percent of the rock, feldspar 15 percent, rock fragments 10 percent, and calcite cement 15 percent. The ratio of sandstone to shale is not known quantitatively. In a profile view of the spur east of Lachi Khan, a longitudinal section 5,000 feet thick was estimated to contain 15 percent sandstone and 85 percent shale.

\section{ORIGIN AND AGE}

The environment of deposition and the source of the Murree rocks has been much discussed. To explain the red color of the Murree, Wadia (1931, p. 217) concluded that the source area was the iron-bearing Cuddapah and Dharar rocks far to the south in the Indian Peninsula. It does not seem reasonable, how- ever, to postulate a basin receiving sediments from the south at a time when the rising axis of the Himalaya immediately to the north must have been shedding great amounts of detritus southward. The present existence of red soils and much decayed red rocks in the Indian Peninsula does not prove a source area from that direction. The rising mountains to the north must also have been subjected to intense chemical weathering under warm humid conditions, and as a result, a red soil would also have formed there, which would have provided the coloring material for the Murree rocks. A much shorter transport than from the Indian Peninsula is indicated by the marked angularity of quartz and feldspar grains in the sandstone.

The Murree Formation is generally regarded as early to middle Miocene in age on the basis of leaf impressions (Feistmantel, 1882) and on stratigraphic grounds (Pilgrim, 1910, p. 187-188). However, the gradational contact with the underlying Eocene limestone of the Kala Chitta Group indicates that the lower part of the Murree Formation may be Oligocene in age.

\section{QUATERNARY DEPOSITS}

Quaternary deposits consist mainly of reworked loess and stream deposits, which include a system of terraces along the main rivers and larger creeks. The most widespread deposits of loess are found in the lowlands of the Haripur area, in the Abbottabad area, and in the upland plain between Mansehra and Shinkiari. The loess is partly consolidated and interlayered with sand and gravel, indicating some reworking. The streams have deeply incised these deposits, forming nearly vertical gullies as much as 200 feet deep.

The Indus River flows in a narrow flood plain composed of silt and sand. Bedrock reaches the edge of the river only in a few places in the mapped area. Adjacent to the flood plain, remains of boulder terraces stand several hundred feet above the present river level.

Alluvial deposits and associated terraces also are found along the Siran and Kunhar Rivers, but these rivers flow in bedrock throughout much of their courses. The only alluvial deposits associated with the Kishanganga and Jhelum Rivers are those at Muzaffarabad. North and east of Muzaffarabad, the Kishanganga River flows in a deep canyon lacking stream deposits.

Many of the small patches of alluvium shown on plate 2 are mainly stream-laid sand, gravel, and boulder deposits formed along the larger creeks. The alluvial deposits at Battal are composed mainly of slightly reworked weathered surface material formed on the Mansehra Granite. 


\section{INTRUSIVE ROCKS}

\section{MANSEHRA GRANITE}

The name "Mansehra Granite" was given by Shams $(1961$, p. 59$)$ to the nonfoliated granite found locally in and around Mansehra village. He also distinguished a foliated granite, which was called the "Susal Gali granite gneiss" (Shams, 1961, p. 60), and a tourmaline granite called the "Hakale granite" (Shams, 1961, p. 61). In a later paper, Shams stated that these various granites are genetically related, differing only in their location and level of emplacement (Shams and Rahman, 1966, p. 49). In the Mansehra area, Offield combined all three varieties into one unit called the Mansehra Granite, and Offield's usage is followed here.

The Mansehra Granite underlies large parts of the central and northern parts of the map area. Its southern and eastern margin extends in a broad arc from near Darband on the Indus eastward through Mansehra, then north past Garhi Habibullah along the western flank of the syntaxis. Narrow belts of this unit also are seen on the eastern flank of the syntaxis near Mahandri.

The Mansehra Granite is considered to represent the southern fringes of the extensive granite intrusions in the axial zone of the Great Himalaya, which have been called the "Central Himalayan Gneiss" (Stoliczka, 1865 , p. 15). Middlemiss (1896) called the granite rocks in the Hazara area the "Gneissose granites." There is no direct basis for determining the minimum age of the granite in this area, because the youngest rocks intruded belong to the Tanawal Formation of Ordovician(?) to Devonian(?) age. Similar granite intrudes Cretaceous rocks of the Astor-Burzil area in Kashmir (Wadia, 1937, p. 154). A sample of granite collected by R. G. Davies, Panjab University, was determined to be 80 million years old, which is Late Cretaceous. On the basis of the intrusive relations in the Astor-Burzil area, the age determination by Davies, and structural information in the mapped area, the Mansehra Granite may be considered as Late Cretaceous to early Tertiary (Eocene) in age, synchronous with the early phases of the Tertiary Himalayan orogeny.

The Mansehra Granite is generally foliated except in the area around Mansehra. Contacts with the adjacent rocks are sharp and concordant with foliation. In a few places the contact is a shear zone. Although general concordance is the rule, in places the contact is marked by the presence of seams and stringers of granitic material cutting across the adjacent rocks and by inclusions of the adjacent rocks in the granite. There is no doubt about the intrusive character of the granite.
The granite is light colored, medium to coarse grained, and is characterized nearly everywhere by large phenocrysts of twinned microcline, some as much as 5 inches long. The main mineral constituents are microcline, oligoclase, and quartz, with small amounts of biotite and muscovite and accessory magnetite, apatite, and sphene. Quartz content ranges from 10-20 percent. The tourmaline granite contains a greater amount of quartz (30-35 percent) and abundant accessory black tourmaline. Foliation in the granite is expressed by the alinement of microcline phenocrysts and micas. In places the phenocrysts have a swirled pattern.

In general, a pronounced contact aureole around the granite is absent. In most places there is very little alteration of the country rock; in other places, for example, at Batrasi Summit west of Garhi Habibullah and near Susal Gali southeast of Oghi, a zone of cordierite schist has formed.

The configuration of the contact near Batrasi Summit and in the Giddarpur and Oghi areas and the fact that the metamorphic rocks in many places dip under the granite suggest that the granite is sheetlike in form and that it has been folded with the metamorphic rocks. Homogeneity of structure in the granite and the surrounding rocks indicates the deformation of a layered sequence of which the granite was part. Rahman (1961, p. 20), in a gravity study of the Mansehra area, found no anomaly, and from this he also concluded that the granite is sheetlike in form.

\section{STRUCTURE}

\section{REGIONAL SETTING}

The structural setting of the southern Hazara district in relation to the Himalayan mountain system as a whole is shown on plate 1 . The mapped area is at the pivot point of a great regional arc which includes the entire 200-mile width of the Himalaya. After following a gently curving arc for 1,000 miles across northern India and Kashmir, the geologic structures abruptly turn back upon themselves to form a tight loop or reentrant which occupies the eastern third of the mapped area (pls. 1, 2; fig. 1). This tight loop or reentrant was first described by Wadia (1931), who called it the "Syntaxis of the Northwest Himalaya." In the present report, it is referred to as the "Hazara-Kashmir syntaxis," or "syntaxis."

West of the syntaxis, the structures describe a broad arc, here called the "western arc," which trends southwest past Abbottabad, then west toward the Indus River. Near the Indus River the structures turn northward, then once again turn sharply back on themselves to form another sharp bend, here called the "Indus 
reentrant." On the west side of the Indus River, the structures turn south, then southwest, and finally take a westward course toward Kohat. As mapping of the Indus reentrant is not complete, the structure of this reentrant is not very well known.

Southeast of the mapped area, along the foothills of the Himalaya, the general structural picture, as interpreted by Wadia and others, consists of a series of nappes or large recumbent folds which have moved southward relative to the underlying rocks along major thrust faults. This nappe belt, called the "Nappe zone of the Himalayas" (Wadia, 1957, p. 418), is thought to extend from the Pir Panjal Range at least to Simla, 200 miles to the northeast where West $(1939$, p. 162) described the Simla nappe. Southeast of Simla at Garhwal, Auden (1937, p. 432) described two main nappes which involve minimum displacements of 22 and 30 miles.

In the foothills of the Pir Panjal Range, southeast of the Hazara area, Wadia (1957, p. 418-419) mapped two more or less parallel and persistent thrust faults which extend the full length of the range from the Jhelum to the Ravi Rivers. The inner of these, which he called the Panjal thrust, is considered to be the basal sliding plane of a large nappe, called the Kashmir nappe. The slate and schist of the Purana Series (Precambrian) have moved southward from the central mountains over rocks of Carboniferous to Eocene age. Along the outer thrust, which he called the Murree thrust, Carboniferous to Eocene rocks have moved southward over rocks of the Murree Formation. In an earlier paper Wadia $(1931$, p. 215$)$ stated that the Murree thrust actually is a reverse fault.

\section{HAZARA-KASHMIR SYNTAXIS}

The outer (southern) ranges of the Himalaya, which extend northwestward for 1,000 miles in a gentle unbroken curve across northern India, continue into Kashmir and the Hazara district of Pakistan where they form the eastern limb of the syntaxis. Essentially continuous, the major faults and most of the geologic units turn abruptly westward at Paras to form the apex of the syntaxis and then southeastward to form the western limb.

The two main boundary faults that wrap around the syntaxis (fig. $1 ;$ pl. 2) are considered equivalent to Wadia's Panjal and Murree faults and are so named in this report.

The axis of the syntaxis is oriented slightly west of north, and the outcrop width of the youngest rocks in the axial zone is barely 10 miles. Not only are the outer (southern) ranges of the Himalaya inflected, but a similar bend in the regional strike is evident for 200 miles to the north, beyond the central axis of the inner
Himalaya, although the sharpness of curvature gradually decreases northward. The axial zone of the syntaxis thus is the pivot point of the great regional bend that involves the entire width of the Himalaya (pl. 1).

Stratigraphically, the syntaxis contains the youngest rocks in its core, or axial zone; successively older rocks wrap around the periphery. The Murree Formation (Oligocene(?) to Miocene) occupies the core; carbonate rocks and volcanic greenstone (Carboniferous to Eocene) wrap around the Murree Formation, and these are followed by metamorphic rocks of low to high grade (pre-Carboniferous), which include slate, phyllite, marble, and quartzo-feldspathic schist of the Tanawal, Hazara, and Salkhala Formations. The Siwalik Group (Miocene to Pleistocene), the youngest rocks involved in the formation of the syntaxis, overlies the Murree Formation south of the mapped area.

\section{EAST LIMB AND APEX OF THE SYNTAXIS}

On the east limb of the syntaxis, from the Kishanganga River north to the apex, the Panjal and Murree faults separate the Carboniferous to Eocene zone of rocks from the older Salkhala rocks on the east and Murree rocks on the west. These faults generally are steeply dipping reverse faults rather than thrust faults, however, and the "Nappe zone of the Himalayas," as envisaged in the northwest Himalaya, is not evident here. At Nauseri on the Kishanganga River, for example, the Murree fault dips $80^{\circ} \mathrm{E}$. to vertical, and just north of the Pakistan-Kashmir divide, the Panjal fault is vertical. For a few miles on either side of Duliar, the Panjal and Murree faults merge, and the rocks of the Salkhala Formation abut the Murree rocks of the axial zone.

The two main faults curve around the apex of the syntaxis and help to define it. The faults are reverse faults, dipping from $45^{\circ}$ to $75^{\circ} \mathrm{N}$. They may flatten out into thrust faults downward and northward, but direct observations have not established this. The rocks in the apex area have been deformed into a series of tight isoclinal folds, vertical or slightly overturned towards the south. Bedding planes and geologic contacts are nearly everywhere sheared.

\section{WEST LIMB OF THE SYNTAXIS}

The Panjal and Murree faults continue around the apex of the syntaxis and down the western limb, the Panjal fault separating the Salkhala rocks from rocks of Carboniferous age and the Murree fault separating Carboniferous rocks from rocks of the Murree Formation. North of Balakot, the Panjal fault merges with the Murree fault, the combined faults continuing southward under the valley alluvium. North of Balakot the dip of the combined faults is $90^{\circ}$. 
South of Balakot, on the steep slope west of the Kunhar River, a small outcrop of the Murree Formation abuts rocks of the Salkhala Formation along a fault zone that dips about $35^{\circ} \mathrm{W}$. The Murree Formation itself is strongly sheared, and in addition to Murree rocks, the outcrop area contains sheared slices of dolomite belonging to the Kingriali Formation. Some of the shears even dip east, toward the river, rather than west. A wide fault zone probably exists under the valley alluvium of the Kunhar River, marking the continuation of the Murree and Panjal faults.

As in the apex area, the rocks in the vicinity of Balakot are deformed into tight isoclinal folds, the limbs of which dip vertically or steeply west.

At a point 4 miles south of Balakot, the Murree and Panjal faults separate from one another and divide the southern two-thirds of the mapped area into three main structural units or blocks: (1) the area west of the Panjal fault, which includes the western arc area and the Indus reentrant; (2) the Garhi Habibullah syncline between the Panjal and Murree faults; and (3) the area east of the Murree fault, which constitutes the axial zone itself. Although the three areas have similar structural patterns, there is evidence that they have moved as individual blocks along the master faults. Both reverse as well as left-lateral strike-slip movements have taken place along the master faults. Each individual block has moved south and up relative to its adjacent eastern neighbor, and each block also has its own characteristic stratigraphy.

On the western limb of the syntaxis, large fault movements took place during the late Tertiary along the Panjal and Murree faults, as the Murree Formation (Oligocene(?) to Miocene) is involved in the faulting. However, certain stratigraphic anomalies from one block to another indicate, in addition, that significant vertical movements evidently occurred during the Paleozoic and Mesozoic, long before the Tertiary Himalayan orogeny. These anomalous stratigraphic relations, depicted in figure 2, are as follows:

1. The Tanawal Formation, which has an outcrop width of 4 miles in the area west of the Panjal fault, is absent east of the fault. East of the Panjal fault, rocks of the Kingriali Formation rest directly on the Hazara Formation.

2. The thick sequence of Jurassic and Cretaceous rocks in the Garhi Habibullah syncline west of the Murree fault is absent in the axial zone of the syntaxis east of the fault. East of the Murree fault, Paleocene to Eocene limestone (Kala Chitta Group) rests directly on the Kingriali Formation.

The resulting stratgraphic and structural pattern is probably a combination of contemporaneous deformation during sedimentation as well as the juxtaposition of dissimilar blocks.
On the western limb of the syntaxis, the Panjal fault is the master fault separating the rocks of the Garhi Habibullah syncline from the rocks to the west. Along this fault the slate and quartzose schist of the Hazara and Tanawal Formation abut the younger rocks of the trough of the Garhi Habibullah syncline. North of the Garhi Habibullah village, the Panjal fault is inferred to follow the valley of the Kunhar River and to join the Murree fault near Hassa, 3 miles south of Balakot. The intersection of the Panjal and Murree faults marks the apex of the Garhi Habibullah synclinal block.

The Panjal fault is a combination reverse-strike-slip fault which dips from $59^{\circ} \mathrm{E}$. to vertical. Although, fundamentally, the block on the west side of the Panjal fault is relatively uplifted $(6,500 \mathrm{ft}$ of stratigraphic displacement), significant later movement has caused the younger rocks within the syncline to move westward over the older Hazara and Tanawal rocks. South of Tarnawai village the Panjal fault steepens to $90^{\circ}$ and then changes into a thrust fault, along which the rocks of the Tanawal Formation have ridden southward over younger rocks. This configuration provides direct evidence of left-lateral movement. Five miles to the west this thrust fault changes back into a steeply dipping fault which continues to the alluvium of the Haripur Plain. The amount of left-lateral displacement along the Panjal fault is unknown, but 4 miles of displacement is possible, according to the inferred offset of the Hazara Formation between Garhi Habibullah and Hassa, 3 miles south of Balakot.

On the western limb of the syntaxis, the Murree fault is the main boundary fault separating the rocks of the eastern flank of the Garhi Habibullah syncline from the generally younger rocks in the axial zone of the syntaxis on the east. This master fault extends continuously from near Hassa southeastward to Muzaffarabad and thence south along the Jhelum River as far as Kohala. Northwest of Muzaffarabad the Murree fault dips from $50^{\circ}$ to $70^{\circ} \mathrm{E}$.; south of Muzaffarabad it steepens to $80^{\circ} \mathrm{E}$. and in places is vertical. As with the Panjal fault, a large component of vertical displacement has raised the rocks west of the fault relative to the rocks of the axial zone east of the fault. Vertical stratigraphic displacement is about 10,000 feet, and like the movement along the Janjal fault, a similar westward countermovement of younger rocks over older rocks took place along the Murree fault during the later development of the syntaxis. Strike-slip movement along the Murree fault is not directly evident, although the horsetail structure south of Hassa and the variation in dip along the fault are features commonly associated with strike-slip movement.

In the area between the Panjal and Murree faults, the general structure is a south-plunging syncline, the Garhi Habibullah syncline, in which younger sedimen- 
tary rocks in the trough are underlain unconformably on the east by older low-grade metamorphic rocks and faulted on the west by the Panjal fault. The Garhi Habibullah syncline, which is simple at Garhi Habibullah (although overturned westward), opens up southward and becomes very complex, virtually losing its identity except in gross aspect. The southwestward continuation of this complex structure across Sirban Hill has not been worked out and therefore is generalized on the geologic map (pl. 2).

The sedimentary rocks within the Garhi Habibullah syncline have been deformed into a series of doubly plunging, north- to northeast-trending folds subsidiary to the large synclinal structure. The relatively thin and persistent beds of the Datta Formation, which are highly conspicuous because of their red color, serve to outline the main features of this small area. The folds are tight, attenuated, nearly isoclinal, and commonly are broken along one limb by reverse faults. In places, for example just northeast of Kakul, the folds are completely disrupted by many strike faults, resulting in a series of fault slices. The faults in this area are nearly vertical, and large drag folds are sharp crested and symmetrical and have vertical axial planes.

In general, the fault pattern in the area between Kakul and Garhi Habibullah is a system of anastomosing faults which parallel the strike of the beds for considerable distances. Several faults converge toward Kakul, and very likely continue southwest under alluvium as a single master fault. Most of the subsidiary faults within the syncline are fold faults that have originated during the latter stages of folding by rupture along one limb of a fold. The close relationship between folding and faulting is self evident in parts of this area of detailed study, but in other parts, further adjustments to continued deformation took place along the fold faults and eventually obliterated the fold pattern. The zone of faults just north of Kakul exemplifies continued deformation by faulting, the end result being a series of fault slices.

Between Kakul and Garhi Habibullah the so-called fold faults dip in the same direction as the bedding in a given area. Most of them dip from $50^{\circ} \mathrm{E}$. to vertical, in harmony with the westward sense of overturning of the Garhi Habibullah syncline and many of the subsidiary folds within it. However, a few subsidiary faults dip from $40^{\circ}$ to as low as $20^{\circ} \mathrm{W}$. and are more like thrust faults. These latter faults, with their associated recumbent folds, imply eastward movement, whereas the first group of faults indicates westward movement. This conflicting structural picture is related to the westward countermovement mentioned previously and is discussed further in the section on "Interpretation."

It should be noted that a reversal in dip of the master faults and in the sense of the vertical component of displacement takes place along the west limb of the syntaxis. Whereas the faults in the vicinity of and north of Balakot dip vertically or to the west with the west side upthrown, the faults a short distance south of Balakot in the Garhi Habibullah and Muzaffarabad areas dip east with the east side upthrown. The former configuration implies movement of older rocks upward and toward the axial zone of the syntaxis, whereas the latter indicates movement of the younger rocks upward and southwestward away from the axial zone of the syntaxis. This reversal takes place near Hassa, 3 miles south of Balakot, where the details of the change are hidden from view by valley alluvium. The horsetail structure 2 miles southeast of Hassa very likely is associated with the reversal of dip. The southwestward sense of movement in the Garhi Habibullah and Muzaffarabad areas is shown not only by the eastward dip of the faults but by the asymmetry of the Muzaffarabad anticline, which is sharply overturned southwestward. This southwestward assymmetry is considered to be a late-phase countermovement superimposed on the earlier fault movements of the area.

\section{AXIAL ZONE OF THE SYNTAXIS}

The axial zone of the syntaxis is composed almost entirely of the Murree Formation, except for the Carboniferous to Eocene rocks in the Muzaffarabad anticline and several thin north-trending outcrops of Eocene limestone on the high divide between Pakistan and Kashmir. Presumably these latter outcrops are fault slices and inliers in the centers of denuded tight folds. In this rugged area, with local relief exceeding 8,000 feet, it is peculiar that the underlying Eocene limestone is not exposed in more places within the axial zone. Evidently the Murree Formation is quite thick, and its apparent thickness is even greater, owing to folding. Southeast of Lachi Khan a minimum thickness of 5,000 feet of continuous undisturbed exposure can be seen on a mountain face between the Kashmir divide and the Kishanganga River.

The Muzaffarabad anticline on the western edge of the axial zone trends southeast, is sharply overturned southwest, and is crossfolded. Within the overturned southwestern limb of this anticline, a second fault, the Muzaffarabad fault, separates Carboniferous to Triassic rocks (Kingriali Formation) from the younger rocks. This fault dips $25^{\circ}-50^{\circ} \mathrm{E}$., and along this slanting surface the Carboniferous to Triassic rocks have moved westward over the Eocene limestone and Murree rocks. The Eocene limestone and Murree rocks of the overturned southwestern limb of the Muzaffarabad anticline are sandwiched between the Murree and Muzaffarabad faults and in places are cut out altogether. North of Garhi Habibullah, the Muzaffarabad 
fault joins the Murree fault; southeastward it decreases in displacement and disappears.

The folds in the Murree rocks of the axial zone have a horseshoe-shaped pattern on the map (pl. 2) and follow approximately the curve of the apex. On both limbs of the syntaxis, the folds swing into parallelism with the boundary faults. In the hills southeast of Muzaffarabad, eight symmetric folds trending northeast occur in 1 mile of traverse. The Kishanganga River follows approximately the curving strike of the folds.

It is not known whether the folds were originally straight and later bent into their present horseshoe shape or were formed more or less in their present curved position from the start. In any case these folds have crossfolded the Muzaffarabad anticline and therefore represent the youngest folds recorded in the formation of the syntaxis.

\section{WESTERN ARC}

The western arc is the gently curving structure forming the connection between the Hazara-Kashmir syntaxis and the Indus reentrant (fig. 1). The arcuate trend is made manifest by the Sherwan syncline and the southern margin of the Mansehra Granite. Northward, in the granite and metamorphic rocks, this pattern is still apparent as far north as Battal. North of Battal, the structural trend is mainly north, and the western arc loses its identity.

In the southern part of the western arc, the Kingriali Formation outlines the Sherwan syncline and additional smaller synclines farther south. The Sherwan syncline is doubly plunging, open, and symmetrical in gross aspect, but in places it is internally deformed into subsidiary smaller folds. The western end of the northern limb is overridden by southward-moving rocks of the Tanawal Formation.

Farther north, the contacts between the granite and metamorphic rocks commonly are low dipping. The metamorphic rocks dip under the granite except in the areas of overturned folds. Dips as low as $8^{\circ}$ are recorded north of Oghi, but more commonly they are $35^{\circ}-45^{\circ}$. Between Mansehra and Battal, the metamorphic rocks tend to form elongate bodies oriented approximately east.

\section{INDUS REENTRANT}

The Indus reentrant is so named for the narrow belt along the Indus River where the geologic structures appear to form another northward-projecting loop. Information on the Indus reentrant is incomplete; therefore, the interpretations relating to it are tentative. The actual apex and west flank of this loop were not mapped because of unfavorable tribal conditions.
From Tarbela village in the southwestern part of the mapped area, the axis of the reentrant extends slightly west of north to Dangror Mountain and then north through Amb and Kandar villages (pl. 2). On the east flank the strike of the foliation swings from west to north, and north of Darband the strike turns west around the inferred apex. In the unmapped area west of the Indus, the structural trend was shown by Martin, Siddiqui, and King (1962) to swing southwest and then west toward Mardan. The mapped part of plate 2 north and south of Tarbela likewise shows the swing in structural trend toward the southwest.

The gross arrangement is a tight loop that resembles a north-plunging anticline, the foliation and bedding dipping away from the central axis on both sides. This anticlinal structure is complicated by the Darband fault and by a pair of thrust faults (pl. 2; fig. 1). The relationships among these faults is not entirely clear. South of Darband on the east limb of the reentrant, the Darband fault dips east and then changes to the north-dipping imbricate structure formed by the Dangror and Khar Kot thrust faults. This configuration indicates that left-lateral movement has taken place along the Darband fault. Outcrops of the Dangror and Khar Kot thrust faults are clearly visible in many places. The Khar Kot thrust, marked by a zone of sheared graphitic schist, is exposed at many places along the creek north of Dangror Mountain, and in the creek that drains southwestward from Gandaf village, the Dangror thrust dips $25^{\circ} \mathrm{NW}$. Westward, the two faults are inferred to change back to a single faultthe Darband fault-which continues down the Indus.

Investigations in 1968 at Tarbela damsite (pl. 6) revealed that the Darband fault continues down the Indus River under the river alluvium and emerges as a wide shear zone on the west bank, 2.5 miles below the damsite. From this point the fault turns abruptly northwest where it was traced to the edge of the alluvial cover of the Peshawar Plain. One or more branches of the Darband fault may continue southwestward under the alluvial cover of the Indus River and surrounding alluvial-filled area, but the distribution of rock units on each side of the river, and in particular of a distinctive marker bed at the top of the Hazara Slate, precludes any large displacements along these branch faults.

Along the segment covered by the Indus, the Darband fault would be expected to dip west in conformity with the asymmetry of structure in this area. With this interpretation, the rocks west of the Darband fault have moved relatively upward and southward as a result of reverse and left-lateral movement along the Darband fault. Later westward countermovement on the east limb of the Indus reentrant resulted in east-over-west 
displacement of younger-over-older rocks along the northern, east-dipping segment of the Darband fault. This generalized interpretation conforms to the regional picture of left-lateral movement along boundary faults, but it is subject to revision when more information becomes available.

Mapping is incomplete in the area north of Amb and Darband, and the northern extension of the Darband fault is not known. In this area between Amb and Kandar, the Salkhala and Tanawal Formations make up a folded and faulted sequence, the details of which have not been worked out. The Darband fault may die out northward, or it may continue beyond Amb as a major boundary fault.

\section{SMALL-SCALE STRUCTURES \\ IN THE METAMORPHIC ROCKS}

A structural analysis of the metamorphic rocks in the mapped area is under study by the authors. However, a brief description of the small-scale structures in the metamorphic rocks is included here because these features are helpful in the structural interpretation of the region.

The main structural elements in the metamorphic rocks are foliation, small-scale folds, and various kinds of linear features which include intersections of relatively late cleavage with bedding or foliation, fold and crinkle axes, and mineral-streak lineations.

Foliation generally dips away from the axial zones of both reentrants and dips north in the western arc area. Because of the dominance of isoclinal folding in the metamorphic rocks, foliation is almost everywhere parallel to relict bedding, and, like the bedding, it wraps around both reentrants and follows the curvature of the western arc. Slaty cleavage in the generally isoclinally folded Hazara Formation is equivalent to foliation in the more intensely metamorphosed rocks; a later weakly developed cleavage is marked by chevron folds in the slaty rocks.

Folds range in size from tiny crinkles on foliation surfaces to folds more than 1 mile across. Folds at outcrop scale are of two styles: older flow folds, generally intricate and recumbent, and younger irregular chevron crinkles developed through slip on late cleavage surfaces. Fold-axis lineations in both styles of folds coincide with intersection of cleavage with older planar surfaces.

Mineral-streak lineations are those resulting from the linear orientation (generally giving the impression of streaking out or stretching) of mica, hornblende, quartz, feldspar, and other minerals. In the Tarbela area, elongate conglomerate pebbles provide a welldeveloped lineation substantially parallel to mineralstreak lineations in that area.
Folds of the older generation, associated with the development of foliation and slaty cleavage, have prominent mineral-streak lineations parallel to the fold axes; the fold axes trend generally north throughout the region. The younger folds are less penetrative and less strongly developed than the older flow folds in most of the area; they trend generally east.

In the apex area of the syntaxis, the two generations of folds merge in style and degree of development and are hard to identfy separately in places; large gently plunging folds trending east are dominant and obscure the older folds in part of the apex area. The older folds that are seen, however, plunge northward at steep angles. On the west limb of the syntaxis, the mineral lineations, which trend north and are nearly horizontal, are the most prominent structural elements. In the western arc area, the foliation surfaces contain the older set of mineral lineations and small-scale fold axes. These structural elements plunge north at varying angles, and in a few instances, south. The older small-scale folds are isoclinal recumbent folds overturned to the east and west; they have associated axial planes that strike east and dip north (reclined folds). The later set of chevron crinkles plunges gently to the east and west and is abundantly but weakly developed. In the area of the Indus reentrant, the older northtrending mineral lineations and small-scale folds predominate, although younger folds trending east and overturned south are common in the metamorphic rocks of lower grade.

\section{INTERPRETATION}

\section{LARGE-SCALE TECTONICS}

The structure of the Himalayan mountain system has long been a subject of extraordinary interest because of its magnitude and intensity and because of the relevance it has to the understanding of earth dynamics. Inasmuch as the interpretation of the structure of the mapped area must be integrated into the structure of the Himalayan mountain system as a whole, it is appropriate to mention some of the large tectonic features and problems that relate to this mountain chain.

The Indian and adjacent Asian region is made up of four distinct geologic and physiographic features: (1) the Precambrian shield of the Indian Peninsula; (2) the Himalayan mountain system of folded rocks to the north, west, and east of the Indian Peninsula; (3) the great Indo-Ganges Plain, an alluvial-filled structural depression separating the Indian Peninsula from the mountains; and (4) the high plateaus and mountain ranges of Tibet, the Pamirs, and northern Afghanistan. 
It is well known that the Himalayan mountain system, in the broad view, shows structural asymmetry towards the Indian Peninsula; that is, a pattern of overturning in the general direction of south, together with associated north-dipping faults. Southward asymmetry has been interpreted in two ways: (1) by southward creep of the crust from Middle Asia towards India (Wadia, 1957) or (2) by the creep of India northward under the Asian landmass (Wegener, 1924). The former process involves the idea of overthrusting, the latter process underthrusting. Either process will produce the same geometric result, that is southward asymmetry of the Himalayan structure. Most of the prominent workers who have mapped in the Himalaya interpret the structure in terms of southward mass transport (Auden, 1937; West, 1939; Heim and Gansser, 1939; Wadia, 1931, 1957; Wadia and West, 1964). The convex arcuate trends of the Indo-Burma Himalayan and Iranian ranges away from the center of Asia are taken to indicate a radial spreading out, in a southward direction, of middle Asia. What actually caused Asia to spread out southward is not known.

Recently, a new theory of global tectonics has been developed that strengthens the view that the Indian Peninsula has drifted north against the Asian landmass. The new theory, variously called the "theory of lithosphere plate tectonics," the "new global tectonics," or "the sea-floor spreading hypothesis," utilizes elements from the earlier theories of continental drift (Wegener, 1924) and thermal convection currents in the mantle (Vening Meinesz, 1934; Griggs, 1939), together with recently acquired oceanographic and geomagnetic data. The new ideas offer a unified solution to the origin and development of island arcs, oceanic ridges and trenches, folded mountain belts, and other large tectonic features of the earth. Two recent discussions on this subject were by LePichon (1968) and Dewey and Bird (1970).

Using thermal convection currents in the mantle as the driving mechanism, the new theory proposes that lithosphere plates $150 \mathrm{~km}$ thick are carried along on the upper part of the convection cell at rates ranging from 1 to $10 \mathrm{~cm}$ per year. Lithosphere plates are generated at oceanic ridges, such as the mid-Atlantic Ridge, where the convection current is on the upturn, and plunge downward at the downturn part of the convection cell where plate underthrusting occurs. Migration of the plate is from the upturn part of the convection cell toward the downturn part. In the common case, the downturn or plate underthrusting part of the convection cell takes place in oceanic trenches associated with island arcs or continental margins. Continental masses are carried along as passive passengers on the much thicker plates (Dewey and Bird, 1970, p. 2626).
According to Dewey and Bird (p. 2628), peninsular India has collided with Asia to produce the Himalaya and the wide zone of strong seismic activity across Tibet. LePichon (1968, p. 3663) calculated the spreading rate in the Indian Ocean to range from 1.0 to 3.0 $\mathrm{cm}$ per $\mathrm{yr}$ in a north-northeast direction, which suggests that the Indian subcontinent is still moving against Asia.

The time when India collided with Asia is correlated in general with the Himalayan orogeny. LePichon $(1968$, p. 3693$)$ considered that the first large orogenic stage began in the late Eocene. At this point in time, LePichon believed that India was about $1,000 \mathrm{~km}$ south of the ancestral continental margin of Asia, and between the two continental masses was the Tethys Sea with its accumulating carbonate sediments. Thus, the initial actual collision was against the sediments of the Tethys Sea, and as India continued to move northward, the Tethyan geosyncline developed and eventually became transformed into the Himalaya.

In addition to the origin and direction of the largescale tectonic forces that produced the Himalayan mountain system, there remains the problem of accounting for the great regional arc of the northwest Himalaya, which is more than 200 miles thick and tightens southward into the acute hairpin bend of the Hazara-Kashmir syntaxis of the mapped area. As seen from plate 1, the Himalayan mountain system swings from northeast in the Karakoram Range of northern India and Kashmir to southwest in the Hindu Kush of northern Pakistan and Afghanistan. Southward the curvature gradually becomes sharper, eventually culminating in the hairpin bend of the Hazara-Kashmir syntaxis, which is almost precisely at the pivot point of the arc.

Ignoring first causes for the moment, the resulting syntaxial structure can be explained as follows: The lines of tectonic transport, being perpendicular to the curving regional trend, would converge on the present position of the syntaxis. Such a movement picture, focusing on the present position of the Hazara-Kashmir syntaxis, from the northeast, north, and northwest, eventually would force the geologic structures and rock units to wrap around a core zone, compress the younger rocks within the core zone, and a structure such as the present syntaxis would be the natural result.

According to Wadia (1931) the driving forces that brought this about originated in the lateral or radial spreading out of central Asia. Wadia pictured a series of "orogenic wave fronts" moving southward and molding themselves around a buried, north-projecting prong of the Indian Peninsula. Under the new global tectonics, the north-projecting apex of the Indian Peninsula acted like the prow of a ship, and as India moved 
northward, the rocks of the mobile belt of the Tethyan geosyncline molded themselves around the apex. The two views stated above are similar, except that Wadia assumes absolute movement southward, whereas the new global tectonics calls for absolute movement northward.

The structure within the mapped area appears to offer no independent means of determining the causes or absolute direction of tectonic movement in the Himalaya. This problem is continental or global in scope, and the new concept of global tectonics shows promise of leading to a general solution.

With regard to the time of the Himalayan orogeny, perhaps the earliest indications in Pakistan of this event come from the Hindubagh area, near Quetta, where Rossman (oral commun., 1970) found that the rocks of the Hindubagh ultramafic complex have been emplaced by thrust faulting over rocks of Cretaceous age, and the ultramafic rocks in turn were peneplaned, deeply weathered, and then overlain by limestone of Eocene age. The episode of emplacement was later than that of the deposition of the Cretaceous rocks but before the deposition of the Eocene rocks. In the syntaxial area of this report, the earliest indications of the Himalayan orogeny are reflected in the clastic rocks of the Murree Formation (Oligocene(?) to Miocene). The main deformation began somewhat later, inasmuch as the Murree Formation is involved in the main folding. The main folding in the Hindubagh area also began in Miocene time, as is the case throughout Pakistan.

In Iran, Stöcklin (1968, p. 1243-1244) stated that the Alpine orogeny proper began in Late Cretaceous time, but that earlier precursory phases took place in the Late Triassic and in the Late Jurassic-Early Cretaceous.

\section{DETAILED INTERPRETATION}

Within the larger framework discussed, the interpretation of the structure of the mapped area is of itself a subject of more than passing interest because of its position at the focal point of all the stresses generated during the development of the great arc of the Himalaya.

It should be noted that so far as the structural interpretation of the mapped area itself is concerned, it makes no difference whether the absolute direction of movement was from the north in the form of overthrusting or from the south in the form of underthrusting. If it is true, as seems likely, that the Indian Peninsula moved against Asia, then the Himalaya in the region of the mapped area probably were actually forced backward (northward) during the underthrusting process, while at the same time they developed all the surface characteristics of southward mass transport.
These relationships are very difficult to deal with in a literal or absolute manner in the structural description and interpretation of a finite area. Therefore, the following discussion uses the conventional procedure of assuming that tectonic transport took place in the direction pointed to by the asymmetric structures seen on the surface, which in this case is in the general direction of south.

The overall structural pattern, as shown on plates 1 and 2 and in figure 1, consists of two northward-projecting structural loops or reentrants connected by a broad arcuate belt. The larger reentrant, the HazaraKashmir syntaxis, was the subject of considerable study by Wadia (1931), but the existence of the Indus reentrant was not recognized previously.

Deformation in its early stages is pictured as a general tectonic transport relatively away from the central axis of the rising Himalaya. When the great Himalayan arc began its development, the lines of tectonic transport, remaining perpendicular to the structural trend, began to focus on the present location of the syntaxis.

Southwestward tectonic transport along the east limb of the syntaxis is demonstrated by the known system of thrust or reverse faults in the Pir Panjal Range southwest of the mapped area (Wadia, 1931). Southwestward asymmetry along the east limb also is noted within the mapped area at Nauseri, where Carboniferous rocks have moved southwestward over the Murree rocks of the axial zone along the nearly vertical boundary fault.

On the shorter west limb of the syntaxis, the present structural pattern developed in two principal phases of deformation, successive and related parts of the overall picture of the tectonic convergence, towards the developing axial zone of the syntaxis. In the first phase, tectonic transport was generally southward, together with a strong component of pressure to the east and southeast as the southward-moving rock masses impinged against the early-forming axial zone of the syntaxis. Southward transport is inferred from north-trending mineral-streak lineations, left-lateral movement along the Panjal fault, and the north-dipping pair of thrust faults north of Abbottabad. Mineral-streak lineations parallel to fold axes in the granite and metamorphic rocks are taken as evidence of extension and flow folding parallel to the direction of tectonic transport, which initially was generally southward. In keeping with the picture of the relative southward translation of rock masses, left-lateral displacement also is inferred along the Murree fault on the west limb of the syntaxis, although direct evidence of this is lacking. On this basis, the Murree fault on the west limb of the syntaxis is believed to have formed in response to shearing stresses set up between the relatively stationary rocks 
of the axial zone and the southward-moving rocks on the west.

Between Abbottabad and Balakot, the Panjal fault formed when the area of the Garhi Habibullah syncline lagged behind the western arc area. Thus the area along the southern part of the west limb of the early-forming syntaxial bend became divided into three structural areas, or blocks, separated by strike-slip faults. In the southern part of the mapped area, left-lateral movement along the Panjal fault changed, for a short stretch, to southward movement along a pair of north-dipping thrust faults.

General southward movement along the west limb of the syntaxis was accompanied by a strong component of pressure directed southeastward, particularly in the southern part where the tectonic trend fans out to the southwest. This southeastward component resulted in significant vertical movement along the main strikeslip faults, the west side being upthrown relative to the east side. The Panjal and Murree faults on the west limb of the syntaxis thus are combination strike-slip reverse faults. The west-dipping faults within the Garhi Habibullah syncline also formed in response to the southeastward component of movement.

The second phase of deformation was a southwestward and westward countermovement of rocks in the axial zone, manifested in the westward overturning of major folds in the Kakul, Garhi, Habibullah, and Muzaffarabad areas and east-over-west displacement of younger-over-older rocks along the Panjal, Murree, and Muzaffarabad faults. This is the most evident phase of deformation in this local area and tends to mask the earlier phase. On the scale of the Hazara-Kashmir syntaxis as a whole, this westward asymmetry is a local development, restricted almost entirely to the southern segment of the west limb of the syntaxis. The second phase is interpreted as an extrusion westward of the highly compressed rocks in the axial zone of the syntaxis in response to continued southward and southwestward movement of rocks on the longer east limb of the syntaxis. Westward countermovement also was accompanied by continued southward movement of the rocks along the west limb of the syntaxis, which accounts for the changes in dips along the major faults. The continued squeezing together of the limbs of the syntaxis completed the horseshoe-shaped fold pattern within the axial zone and refolded the Muzaffarabad anticline and the Muzaffarabad fault. These are the latest folds recorded in the mapped area.

Between the Hazara-Kashmir syntaxis and the Indus reentrant, the rocks have moved south to form the southward bulge of the western arc. Deformation in the granite and metamorphic rocks to the north is characterized by recumbent flow folds overturned east and west, with axial planes dipping north (reclined folds). In the southern part of the western arc where metamorphism is less intense and southward transport became impeded, the rock masses began to crumple around axes approximately perpendicular to the direction of movement, and compressional deformation became general, supplanting extension and flowage. This compressional phase produced the Sherwan syncline and associated folds in the southern part of the western arc, and it also is manifested in the second-generation crinkles and axial-slip cleavage in the metamorphic rocks to the north.

Not enough information is available to provide a complete interpretation of the Indus reentrant. As with the Hazara-Kashmir syntaxis, it seems clear that strong components of movement were directed toward the axial zone from both limbs. The nature of the apex area, assuming it exists, is unknown. Unlike the HazaraKashmir syntaxis, however, not only the western limb of the Indus reentrant, but also the axial zone, underwent relative southward movement, as indicated by the north-dipping thrust faults and the left-lateral strikeslip displacement along the Darband fault. By this interpretation, the rocks west of the Darband fault moved south as a unit relative to the rocks east of the fault, and at the same time, components of movement were taking place toward the axial zone from the east and west.

\section{REFERENCES CITED}

Ahmad, Aftab, 1961, Olcostephanus astierianus newly recorded from Hazara: Panjab Univ. Geol. Bull. 1, p. 65-66.

Ali, C. M., 1962, The stratigraphy of the southwestern Tanol area, Hazara, West Pakistan: Panjab Univ. Geol. Bull. 2, p. 31-38.

Auden, J. B., 1937, The structure of the Himalayas in Garhwal: India Geol. Survey Recs., v. 71, pt. 4, p. 407-433.

Boucot, A. J. and Gauri, K. L., 1968, Age and relationship of basal Muth quartzite of Kashmir, India [abs.]: Geol. Soc. America, Ann. Mtg., Mexico City, 1968, Program with Abstracts, p. 33.

Davies, L. M., 1930, The fossil fauna of the Samana Range and some neighbouring areas; Part 1, An introductory note: India Geol. Survey Mem. 1, Palaeontologia Indica, new ser., v. $15,15 \mathrm{p}$.

Day, A. E., and others, 1962, Stratigraphic code of Pakistan: Pakistan Geol. Survey Mem., v. 4, pt. 1, 8 p.

Dewey, J. F., and Bird, J. M., 1970, Mountain belts and the new global tectonics: Jour. Geophys. Research, v. 75, no. 14, p. 2625-2647.

Feistmantel, Ottokar, 1882, Note on remains of palm leaves from the (Tertiary) Murree and Kasauli beds in India: India Geol. Survey Recs., v. 15, p. 51-53.

Fermor, L. L., 1931, General report of the Geological Survey of India for the year 1930: India Geol. Survey Recs., v. 65, p. 1-160.

Gee, E. R., 1945, The age of the Saline Series of the Punjab and of Kohat: Natl. Acad. Sci. India Proc., Sec. B, v. 14, pt. 6, p. $269-310$. 
Griggs, D. T., 1939, A theory of mountain building: Am. Jour. Sci., v. 237, no. 9, p. 611-650.

Heim, A. A., and Gansser, August, 1939, Central Himalaya: Geological observations of the Swiss Expedition 1936: Schweiz. Naturf. Gesell. Denkschr., v. 73, no. 1, 245 p.

Hemphill, W. R., and Kidwai, A. H., 1973, Stratigraphy of the Bannu and Dera Ismail Khan quadrangles, Pakistan: U.S. Geol. Survey Prof. Paper 716-B, 36 p.

Holland, T. H., and others, 1956, Lexique stratigraphique international; Volume 3, Asie; Fascicule 8a, India, Pakistan, Nepal, Bhutan: Paris, Internat. Geol, Cong., Comm. Stratigraphie, Centre Natl. Recherche Sci., p. 4-281.

Latif, M. A., 1962, An Upper Cretaceous limestone in the Hazara district: Panjab Univ. Geol. Bull. 2, p. 57.

LePichon, Xavier, 1968, Sea-floor spreading and continental drift: Jour. Geophys. Research, v. 73, no. 12, p. 3661-3697.

Lydekker, Richard, 1876, Notes on the geology of the Pir Panjal and-neighbouring districts: India Geol. Survey Recs., v. 9, pt. 2, p. 155-162.

-1878, Notes on the geology of Káshmír, Kistwar, and Pangi: India Geol. Survey Recs., v. 11, p. 30-64.

Marks, P., and Ali, C. M., 1961, The geology of the Abbottabad area, with special reference to the infra-Trias: Panjab Univ. Geol. Bull. 1, p. 47-55.

1962, The Abbottabad formation; a new name for Middlemiss' infra-Trias: Panjab Univ. Geol. Bull. 2, p. 56.

Marks, P., and Ahmad, Aftab, 1962, The Giumal sandstone transgression in the Hazara mountains, West Pakistan: Panjab Univ. Geol. Bull. 2, p. 54-55.

Martin, N. R., Siddiqui, S. F. A., and King. B. H., 1962, A geological reconnaissance of the region between the lower Swat and Indus Rivers of Pakistan: Panjab Univ. Geol. Bull. 2, p. 1-13.

Meissner, C. R., and others, 1973, Stratigraphy of the Kohat quadrangle, Pakistan: U.S. Geol. Survey Prof. Paper, 716-D, $30 \mathrm{p}$.

Middlemiss, C. S., 1896, The geology of Hazara and the Black Mountains: India Geol. Survey Mem., v. 26, 302 p.

1910, A revision of the Silurian-Trias sequence in Kashmir: India Geol. Survey Recs., v. 40, pt. 3, p. 206-260.

Oldham, R. D., 1892, Report on the geology of Thal-Chotili and part of the Mari country: India Geol. Survey Recs., v. 25, pt. 1, p. 18-29.

Pascoe, E. H., 1929, General report [of the Geological Survey of India] for the year 1928: India Geol. Survey Recs., v. 62, p. 1-184.

1959, A manual of the geology of India and Burma, v. 2 [3d ed.]: Calcutta, Govt. India Press, p. 485-1343.

Pilgrim, G. E., 1910, Preliminary note on a revised classification of the Tertiary freshwater deposits of India: India Geol. Survey Recs., v. 40, pt. 3, p. 185-205.

Rahman, Aziz-ur, 1961, A gravity study of the granites in the Mansehra area, West Pakistan: Panjab Univ. Geol. Bull. 1, p. 15-20.
Shams, F. A., 1961. A preliminary account of the Mansehra area, Hazara district, West Pakistan: Panjab Univ. Geol. Bull. 1, p. 57-62.

- 1963, The effect of thermal metamorphism upon calcareous nodules in the quartz-mica schists of the Mansehra area, Hazara district, West Pakistan: Panjab Univ. Geol. Bull. 3, p. 25-27.

Shams, F. A., and Rahman, Fazal-ur, 1966, The petrochemistry of the granitic complex of the Mansehra-Amb State area, northern West Pakistan: Panjab Univ., Jour. Sci. Research, v. 1 , no. 2 , p. $47-55$.

Spath, L. F., 1939, The Cephalopoda of the Neocomian belemnite beds of the Salt Range: India Geol. Survey Mem. 1, Palaeontologia Indica, new ser., v. 25, 154 p.

Stöcklin, Jovan, 1968, Structural history and tectonics of Iran; a review: Am. Assoc. Petroleum Geologists Bull., v. 52, no. 7, p. 1229-1258.

Stoliczka, Ferdinand, 1865, Geological sections across the Himalayan Mountains, from the Wangtu Bridge on the Sutlej to Sungdo on the Indus; with an account of the formations in Spiti, accompanied by a revision of all known fossils from that district: India Geol. Survey Mem., v. 5, pt. 1. p. 1-152.

Vening Meinesz, F. A., 1934, The mechanism of mountain formation in geosynclinal belts: K. Akad. Wetens. Amsterdam, Sec. Sci., Proc., v. 36, no. 4, p. 372-377.

Waagen, Wilhelm, and Wynne, A. B., 1872, The geology of Mount Sirban in the Upper Punjâb: India Geol. Survey Mem., v. 9, pt. 2, p. 331-350.

Wadia, D. N., 1928, The geology of Poonch State (Kashmir) and adjacent portions of the northern Punjab: India Geol. Survey Mem., v. 51, pt. 2, p. 185-370.

1931, The syntaxis of the north-west Himalaya-its rocks, tectonics, and orogeny: India Geol. Survey Recs., v. 65, pt. 2, p. 189-220.

1937, The Cretaceous volcanic series of Astor-Deosai, Kashmir, and its intrusions: India Geol. Survey Recs., v. 72, pt. 2, p. 151-161.

1957, Geology of India [3d ed.]: London, Macmillan and Co., 531 p.

Wadia, D. N., and West, W. D., 1964, Structure of the Himalayas: Internat. Geol. Cong., 22d, New Delhi 1964, 10 p.

Wegener, Alfred, 1924, The origin of continents and oceans [translated from the third German edition, by J. G. A. Skerl]: London, Methuen \& Co., 212 p.

West, W. D., 1939, The structure of the Shali "window," near Simla: India Geol. Survey Recs., v. 74, pt. 1, p. 133-163.

Wynne, A. B., 1874, Notes on the geology of the neighbourhood of Mari hill station in the Punjab: India Geol. Survey Recs., v. 7, pt. 2, p. 64-74.

1879, Further notes on the geology of the upper Punjab: India Geol. Survey Recs., v. 12, pt. 2, p. 114-133.

\# U.S. GOVERNMENT PRINTING OFFICE: $19750-585-471 / 36$ 